\title{
Evaluation of GIS based Ranking and AHP methods in selecting the most suitable site: A case study in Kayseri, Turkey
}

Mehmet Akif Günen ( $\square$ akif@erciyes.edu.tr )

Erciyes Universitesi Mühendislik Fakültesi https://orcid.org/0000-0001-5164-375X

\section{Research Article}

Keywords: Multi criteria decision making, geographic information system, rank based method, AHP, site selection, photovoltaic power plants

Posted Date: March 16th, 2021

DOI: https://doi.org/10.21203/rs.3.rs-239049/v1

License: (c) (i) This work is licensed under a Creative Commons Attribution 4.0 International License.

Read Full License 


\title{
Evaluation of GIS based Ranking and AHP methods in selecting the most suitable site:
}

\section{A case study in Kayseri, Turkey}

\begin{abstract}
Demand for renewable energy sources is increasing since traditional energy sources (i.e., coal, oil, and natural gas) have limited reserves and cause high greenhouse gas emission. Suitable site selection for new generation renewable resources is vital in large-scale projects. In this paper, suitable sites for solar photovoltaic (PV) power plants were selected for a Kayseri, Turkey case. Geographic information systems and multi criteria decision-making (MCDM) methods were integrated to exploit and construct the best location for solar PV power plants. In this context, three main, twelve sub-criteria, and their indicators were determined by considering expert opinion and previous studies. The rank based (i.e., rank sum, rank reciprocal weights, and rank order centroid weights) and analytical hierarchical process (AHP) methods were used to determine the weights of the criteria. The suitability maps created according to the calculated weights were divided into 5 levels (i.e., excellent, good, fair, low, poor site). To compare the success of MCDM methods, 33 existing installed PV power plants were randomly selected and used for validation. It was determined that the rank reciprocal method was the most successful in selection of the most suitable site. Four MCDM methods determined that the Sarız, Tomarza, and Incesu districts of Kayseri were the most suitable sites.
\end{abstract}

Keyword: Multi criteria decision making, geographic information system, rank based method, AHP, site selection, photovoltaic power plants. 


\section{Introduction}

Energy is an indispensable part of the economic development programs of developing countries (Hashemizadeh et al., 2019). It plays a major role in the advancement of countries, increasing competitiveness and the welfare of society. The demand for sufficient, safe, continuous, and clean energy has caused structural changes in the energy supply policies of world countries. There is a transition to renewable energy due to the decrease of existing conventional energy reserves due to demographic evolution, increasing world population, and industrialization. (Aragonés-Beltrán et al., 2014; Uyan, 2017). With the 2015 Paris agreement, some countries signed a memorandum to be effective after 2020. In order to reduce global greenhouse gas emissions, countries have committed to prepare electricity marketing reform packages, reduce electricity consumption, and switch to new generation electricity generation techniques. In this context, the popularity of renewable electricity generation systems, such as wind, solar, hydroelectric, and geothermal has increased. In addition, global warming, climate change, and environmental pollution encourage researchers to expose the potential of renewable energy sources. Since renewable energy sources can be obtained from the ongoing energy flow from the natural process, they have relatively fewer negative effects than other energy sources. Among renewable energy sources, solar energy, which includes different technologies (i.e., photovoltaic panels, concentrated solar power, and solar thermal energy), plays an important role in meeting the world's energy deficit. The attractiveness of solar energy is constantly and rapidly increasing because it is abundant, accessible, free, low-cost, environmentally friendly, and continuous (Choi et al., 2019; Hashemizadeh et al., 2019). Furthermore, solar energy systems have been an alternative energy source due to their ease of operation and maintenance in local regions (Aragonés-Beltrán et al., 2014; Zoghi et al., 2017). Especially in developing countries, such as Turkey, the installation of solar photovoltaic (PV) power plants has become an innovative, dynamic, competitive, and flexible sector. As solar PV power plants installation 
costs are more attractive and they convert solar energy directly into electricity with the help of semiconductor materials, they are more sought-after than concentrated solar power (CSP) systems using reflective material (Choi et al., 2019; Schlecht and Meyer, 2012). Especially, decreases in panel cost prices and technological innovations enable PV systems to compete with traditional energy sources (Renewables, 2017).

PV systems can operate with 5-30\% efficiency depending on the characteristics of their solar cell. The efficiency of PV systems is highly dependent on the conditions of the region in which they are installed (Choi et al., 2019; White et al., 2013). Although there is no exact set of rules for the most suitable solar PV power plants selection, studies conducted so far have led to certain criteria. In this context, solar energy potential, land use / cover, network connection, local climate condition, property, geological structure, and water resources are generally important criteria in studies conducted for different regions (Aydin et al., 2013; Choi et al., 2019; Shorabeh et al., 2019; Solangi et al., 2019).

Based on a wide range of information, the most suitable site selection process maximizes the profit of the project developers and investors (Sánchez-Lozano et al., 2013). It is aimed to decrease installation costs while increasing the annual energy production performance of solar PV power plants. As the site selection is made with different criteria, the limits and characteristics of the relevant criteria (i.e., land use / cover, slope, distance from power line, etc.) change over time (Georgiou and Skarlatos, 2016). Therefore, logical decisions can be made with the Multi-Criteria Decision-Making (MCDM) methods (Richter et al., 2019). In addition, previous studies should be revised and updated according to the new MCDM methods, criteria, and proposed restrictions. Combining Geographic Information Systems (GIS) and MCDM methods is often used to provide detailed planning and accurate information for most suitable site selection for solar PV power plants, GIS provides the collection, analysis, and evaluation of data affecting the solar PV power plants installation in the spatial database. 
MCDM provides comprehensive analysis of spatial databases that can be used by multi-criteria methodologies for a fast and agile solution of the problem. While making the restrictions and definitions of the criteria with GIS software, the weights of the criteria are calculated according to expert opinion with the help of MCDM methods (Colak et al., 2020; Hashemizadeh et al., 2019; Rediske et al., 2020).

MCDM methods have feature strengths and weaknesses. Therefore, the MCDM approach that provides the highest success in solving the region-based location selection problem should be investigated. In the literature, various MCDM methods were integrated with GIS and it was observed that they were presented with customized main and sub-criteria for different study areas (Kamdar et al., 2019). The weights of the criteria of social impact (land transportation, protection area), environmental / technical (land use / cover, distance from water surfaces), and security (distance from airport) were calculated with the Analytic Hierarchy Process (AHP) for solar park selection (Georgiou and Skarlatos, 2016). Tercan et al. (Tercan et al., 2020), used rank based methods such as Rank sum weight (RS), inverse / reciprocal weights (RR), the rank order centroid (ROC) and the point allocation (PA) method to prepare a suitability map for solar PV power plants in Turkey's Mediterranean provinces. Electricity generation resource features (GHI, aspect, slope, elevation), essential features (land use / cover, faults, ground conditions), obligatory features (protected areas, residential areas), infrastructural and complementary features (power network, rivers, water bodies), and logistics / transportation network features (land transportation network, railway transportation network) criteria were used (Tercan et al., 2020). In a study (Zoghi et al., 2017) conducted in Isfahan, Iran, Fuzzy Logic and AHP methods were used to compute the criteria weights of environmental (land use / cover, protected area, wetlands and water resource), geomorphological (elevation, slope, aspect), location (city center, power line, transportation network), and climatic (sunshine, cloudy days, GHI, dusty days, rainy and snowy days, humidity). Hashemizadeh et al. (Hashemizadeh et al., 2019), made the most 
suitable solar PV power plant location selection in Beijing using the Best-Worst Method. Main and sub-criteria were determined by making use of the literature information. In this context, location (urban areas, roads, power lines, waterways), economic (land cost, construction cost), climatic (solar irradiation, average temperature, humidity), and orography (slope, aspect and plot area) criteria were used. In (Sánchez-Lozano et al., 2014), the GIS based Elimination and Choice Translating Reality (ELECTRE) method was used for the most suitable PV solar farm installation in Spain. In another study in Spain, the AHP method for determining the weight of the main criteria and Technique for Order Preference by Similarity to Ideal Solution (TOPSIS) for sub-criteria was used (Sánchez-Lozano et al., 2013). In both studies conducted in Spain, different methods were investigated for the study area. Environment (agrological capacity), orography (slope, aspect, and plot area), location (road, power line, city center and transformers), and climatology (solar irradiation and average temperature) criteria were used. Hafeznia et al. (Hafeznia et al., 2017), used the Fuzzy Logic and Boolean MCDM methods to calculate the weights of criteria. Geographical (slope, aspect, faults, and elevation), technical (road, railway and mining activity), socio-economic (rural area, urban area, etc.,), climatic (GHI, temperature, precipitation) safety (airport, military zone), and land use / cover (RGB band of Sentinel 2A) criteria were used. It was stated that Birjand was the most suitable site and they chose seven special regions for verification of methods on Google maps.

In this paper, rank-based methods (i.e., Rank Sum (RS), Rank reciprocal weights (RR), and Rank order centroid weights (ROC)) and the AHP method were used. The effectiveness of the MCDM methods on site selection of solar PV power plant in Kayseri, one of Turkey's most populous provinces, was investigated. Suitability maps were obtained by calculating main and sub-criteria weights with GIS tools and MCDM methods and reclassified maps were used according to sub-criteria indicators. The suitability map was divided into 5 levels (excellent, good, fair, low, poor site) for qualitative and quantitative presentations. The main and sub- 
criteria used in the study were prepared based on previous studies and the opinions of two experts; topographical and basic conditions (GHI, aspect, slope, land use / cover, bird migration routes), geomorphological \& hydrological conditions (faults, rivers, water surfaces, power line), and infrastructural/superstructure features (road transportation network, railway transportation network, transformer center).

The highest contributions of this paper are below:

- The aim of this research was to examine the effectiveness of four different methods to find the most suitable sites that maximize annual electricity generation by minimizing potential investment costs.

- This comprehensive framework can help stakeholders to install solar PV power plant in developing cities.

- According to the best of our knowledge, rank based methods and the AHP method have not been compared before using GIS in Turkey. Therefore, the relevant methods will be compared for the first time.

- By conducting exhaustive research using real data, the effectiveness of different MCDM methods for the Kayseri case was investigated by using installed solar PV power plants.

-Considering the main and sub-criteria used in the previous studies conducted in different study areas and expert opinion, the most appropriate criteria were determined and inclusive evaluation was made.

The rest of the paper is organized as follows: The MCDM methods are described in Section 2. The study area and the data acquisition are listed in the Material Section. The Results and Discussion are given in Section 4. Finally, the conclusion is presented in Section 5. 


\section{Methods}

MCDM methods rely on an analysis process that maximizes the benefit of the decision maker in managing the decision process according to criteria (Ali et al., 2020). They provide a solution by determining the priorities of the criteria among contradicting alternatives. The optimum result is achieved among alternatives by using two or more consistent main and sub-criteria. Many MCDM methods have been used for optimum solar PV power plant site selection so far. The examination of MCDM methods with different calculation strategies provides a reveal of their superiorities. For this reason, MCDM methods, which are useful and easy to apply, based on ranking and pairwise calculation, were preferred. In this paper, rank-based methods (i.e., rank sum, rank reciprocal, and rank order centroid) and the AHP method were used.

\subsection{Rank Based Methods}

In MCDM methods, weights assigned to the criteria are very important as they directly affect the result. The rank-based methods, which enable weights to be obtained by using their rank instead of directly weighting the criteria, eliminate difficulty and time loss. Decision makers and experts often have difficulty determining the superiority between the criteria. However, they can be more accommodating and flexible in ranking the same criteria. Therefore, even non-experts with little knowledge of the subject often use the rank of criteria to produce useful information. In order to determine weight with rank-based methods, the criteria are first ranked according to their importance and then weights are determined according to the formulas in the method. The RS, RR, and ROC methods were chosen because they have simple structure, effectiveness, and easy application. The formulas of the methods are given in Equations 1-3. In the three rank-based methods used in this paper; $n$ is total number of criteria and $i$ is the rank order of the criteria. 
Rank Sum (RS) (Stillwell et al., 1981): $w_{i}=\frac{n+1-i}{\sum_{j=1}^{n} j}=\frac{2(n+1-i)}{n(n+1)}, i=1,2 \ldots, n$

Rank reciprocal weights (RR) (Stillwell et al., 1981): $w_{i}=\frac{1 / i}{\sum_{j=1}^{n} 1 / j}, i=1,2 \ldots, n$

Rank order centroid weights (ROC) (Barron and Barrett, 1996):

$$
w_{i}=\frac{\sum_{j=1}^{n} 1 / j}{n}, i=1,2 \ldots, n
$$

As seen in Equation 1, the RS method is obtained by normalizing the relevant criterion to sum of ranks. Therefore, the RS method most closely protects the rank order within the set of criteria. In RR (in Equation 2) methods, the "weights are derived from the normalized reciprocals of an attribute's rank" (Stillwell et al., 1981). The ROC (in Equation 3) method determines the centroid of all possible weights, maintaining the rank order of the decision-makers. It also ensures that each weight is achieved by minimizing its maximum error (Barron and Barrett, 1996).

\subsection{AHP}

Another method that is frequently used in the calculation of weights, depending on the main and sub-criteria is AHP. The AHP method, developed by Saaty, is one of the most popular among MCDM methods. The method is mainly based on a pairwise comparison matrix to determine the weights of the main and sub-criteria. Comparison is very important for determining the level at which one criterion is more important than another is. The AHP method generally consists of three components: determining the hierarchy, creating the pairwise comparison matrix, and calculating the weights (Saaty, 2008; Solangi et al., 2019). After the hierarchy is established, Table 1 is used to determine the level of importance among them for binary comparison. 
Table 1. The AHP Method Importance level

\begin{tabular}{|l|l|}
\hline Importance Level & Definition \\
\hline 1 & Equal Important \\
\hline 3 & Moderately Important \\
\hline 5 & More Important \\
\hline 7 & Strongly Important \\
\hline 9 & Extremely Important \\
\hline $2,4,6,8$ & Intermediate Important \\
\hline
\end{tabular}

After the normalized weights of the criteria, determined by the level of importance, the consistency test is performed. The Consistency Index (CI) and Consistency ratio (CR) value is calculated using Equations 4-5 (Saaty, 2008; Solangi et al., 2019).

$$
\begin{gathered}
C I=\frac{\lambda_{\text {max }}-n}{n-1} \\
C R=\frac{C I}{R I}
\end{gathered}
$$

$\lambda_{\max }$ in EQ-2 is the maximum eigenvalue obtained from decomposition of the consistency vector. According to the number of criteria, the appropriate random consistency index (RI) value is selected from Table 2. Binary comparisons are acceptable when the CR value is below 10\% (Saaty, 2008; Solangi et al., 2019).

Table 2. RI value table

\begin{tabular}{|l|l|l|l|l|l|l|l|l|l|l|}
\hline $\mathbf{n}$ & 1 & 2 & 3 & 4 & 5 & 6 & 7 & 8 & 9 & 10 \\
\hline RI & 0 & 0 & 0.058 & 0.90 & 1.12 & 1.24 & 1.32 & 1.41 & 1.45 & 1.49 \\
\hline
\end{tabular}

\section{Materials}

\subsection{Study Area}

The study area covers the provinces of Kayseri, in Turkey. Kayseri is geographically located between $34.5^{\circ}-37^{\circ}$ east longitudes and $39.5^{\circ}-38.5^{\circ}$ north latitudes. The location map of Kayseri is presented in Figure 1. Kayseri is a province in the inner Anatolian region, where solar energy investments are increasing. At the time of the article, there were 24 licensed and 60 unlicensed PV power plants. The total installed power of these power plants is $835 \mathrm{MW}$, with an average annual electricity generation capacity of 2260 GWh (URL-1, Last 
Access:12/07/2020). Considering the insolation and GHI values, Kayseri has very high potential from the surrounding provinces, except for Kahramanmaraş and Niğde. Energy can be provided with more solar PV power plants in Kayseri, which has an organized industrial zone with a high energy requirement. Solar PV power plants should be considered as an alternative energy source, as the industrial potential of Kayseri will increase the need for energy consumption over the years. Therefore, in order to attract investors and ensure maximum performance from solar PV power plants, it is necessary to choose the most suitable location. Another reason for designating Kayseri as a study area is that it is relatively easy to reach rural areas, so investment costs are relatively low.
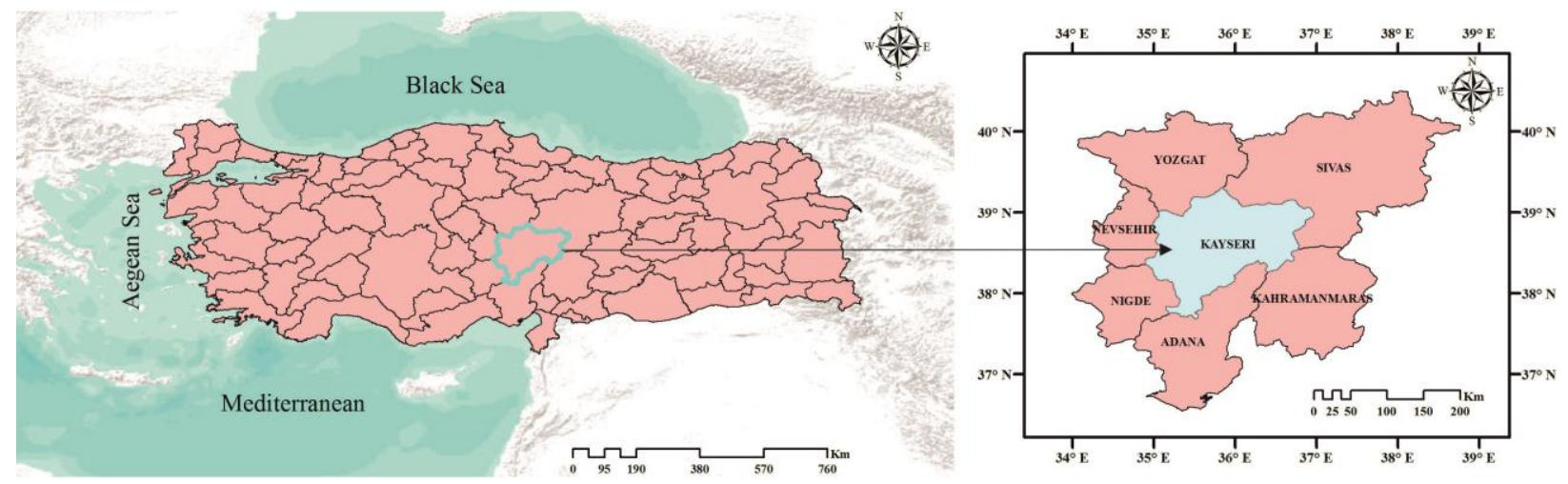

Figure 1. Location map of study area

\subsection{Data Acquisition and GIS}

In this paper, the main, sub-criteria, and indicators of the sub-criteria were created and were based on previous research studies and by two decision makers. It is clear that region-based criteria should be determined in the selection of the most suitable site for solar PV power plants because each region has its own unique topographical texture, character, and structure. In this context, the main criteria was determined as topographical and basic conditions, geomorphological \& hydrological conditions, and infrastructural / superstructure features. Subcriteria were global horizontal irradiation, aspect, slope, land use / cover, bird migration routes, faults, rivers, water surfaces, power line, road transportation network, railway transportation 
network, and transformer center. In this context, the most used criteria in 30 journal studies (i.e., Q1 and Q2 indexes) done with GIS based MCDM methods between 2017-2020 were analyzed in detail from the Web of Science, Scopus, and IEEE Xplore databases (i.e., Keyword: GIS and Solar or PV and site selection or location, or AHP, or Rank, or TOPSIS, or ELECTRE, or Fuzzy Logic). As a result of the analysis, the most used criteria are presented in Figure 2.

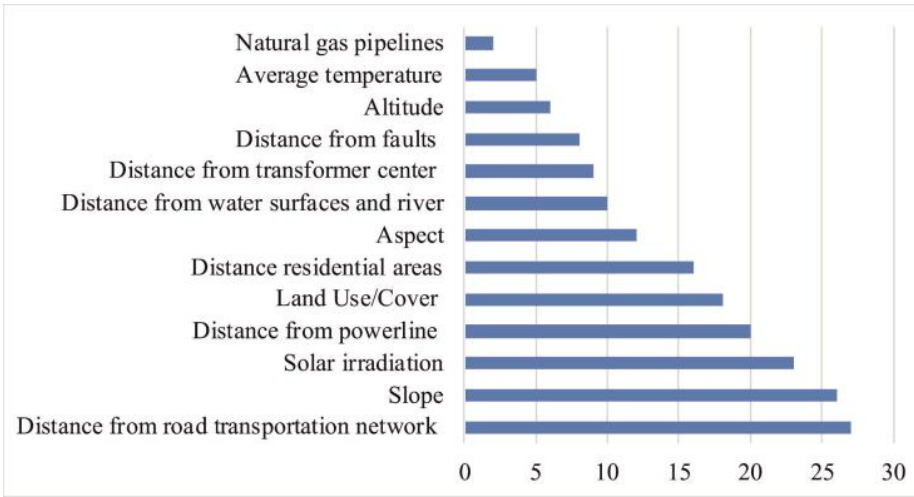

Figure 2. Most used criteria in the literature for solar PV power plant site selection.

The use of all the criteria in Figure 2 was not considered suitable for decision makers in this experimental study area, and the main criteria were created by considering additional criteria that reflect the characteristics of the study area. After determining the indicators of sub-criteria, non-useful areas were determined by defining restrictions using GIS tools. In addition, reclassified maps were created for each MCDM method using GIS tools. Since GIS ensures that vector and raster data from different databases are integrated and kept in a common database, it is effectively used in the site selection of renewable energy sources. GIS tools provide the visualization, editing, identification, analysis, and evaluation of factors affecting the installation of solar PV power plants. In the following sections, the GIS tasks for spatial analysis are reclassification, raster calculation, overlapping, and map algebra, etc. ArcGIS 10.8 software was used for reclassification operations, up-sampling operations, buffer analysis, gathering of non-useful areas, polyline to raster processes, and the preparation of suitability maps. The Digital Elevation Model (DEM) data used in this paper was ASTER with a spatial resolution of $30 \mathrm{~m}$. DEM data of the study area can be downloaded from the website of the 
United States Geological Survey (USGS, Last Access:10/09/2020). DEM data was used to create aspect and slope maps. Since all layers must have common boundaries, all layers were clipped to the Kayseri center city boundaries. Some rules, assumptions, buffers, and restrictions were taken into account to determine non-useful areas by using GIS tools such as; Drinking water facilities (storage, treatment, pumping station, and waste-water areas), prohibited and security areas, park, green areas and daily facility areas, organized industrial zone and free zone areas, cemetery areas, tourism areas, protected areas, $25 \mathrm{~m}$ buffer from rivers, water surfaces, power line, road and railway, and CORINE IDs; Continuous urban fabric (111), Discontinuous urban fabric (112), Industrial or commercial units (121), Road and rail networks and associated land (122), Airports (124), Green urban areas (141), Sport and leisure facilities (142), Broadleaved forest (311), Coniferous forest (312), Mixed forest (313), Beaches, dunes, sands (331), Water courses (511), and Water bodies (512).

The reclassified maps presented in the section below are provided for visualization only. Suitability maps were created by reclassifying them according to the weights calculated with MCDM methods.

\subsubsection{Topographical and basic conditions}

\subsubsection{Global horizontal irradiation (GHI)}

Incoming solar radiation or insolation is one of the most important criteria, with variation depending on topography conditions, and directly affects energy production. Global horizontal irradiance (GHI), which is the sum of ground reflected irradiation, diffuse horizontal irradiation (DHI), and direct normal irradiance (DNI), can be mapped for a certain period. DHI is the amount of solar radiant that is scattered by the molecules, dust, and clouds in the atmosphere, while DNI is the amount of solar radiation in a straight line from the sun (Al Garni and Awasthi, 2017; Hafeznia et al., 2017). Ground reflected irradiation could be eliminated as it has less impact on PV power plant site selection than the other two types of irradiation. GHI maps with 
shortwave radiation are presented online in $\mathrm{kWh}$ per square meter. Maps of GHI, which is shortwave radiation, can be obtained online or with the help of GIS tools. The annual average GHI map for 2019/10, used in this article, was obtained from Global Solar Atlas, which provides reliable data (The World Bank, (Accessed 01/08/2020)). Nominally, the $250 \mathrm{~m}$ resolution map was clipped to the DEM boundary, and then up-sampled according to the spatial resolution of the DEM. A reclassified GHI map is presented in Figure 3.

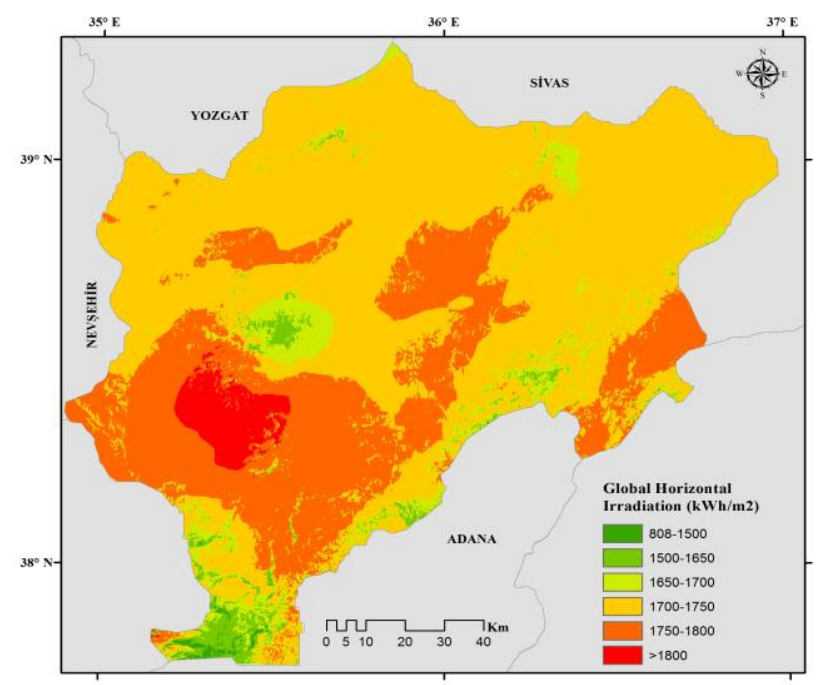

Figure 3. Reclassified GHI map

\subsubsection{Aspect}

The aspect of the solar PV power plant should be considered, as it will increase the amount of solar irradiation from the sun. Aspect criterion was used for bringing forward the south-facing slope of the northern hemisphere for countries, like Turkey. However, it does not mean that other aspects outside the south are insignificant. The aspect map, produced at a spatial resolution of 30 x $30 \mathrm{~m}$ from DEM data, consists of 8 directions, as well as flat terrain (Colak et al., 2020; Solangi et al., 2019). Although flat terrain reduces the installation cost, the flat terrain created in the study is the dam lake surface (i.e., non-useful area). The aspect map of Kayseri is presented in Figure 4. 


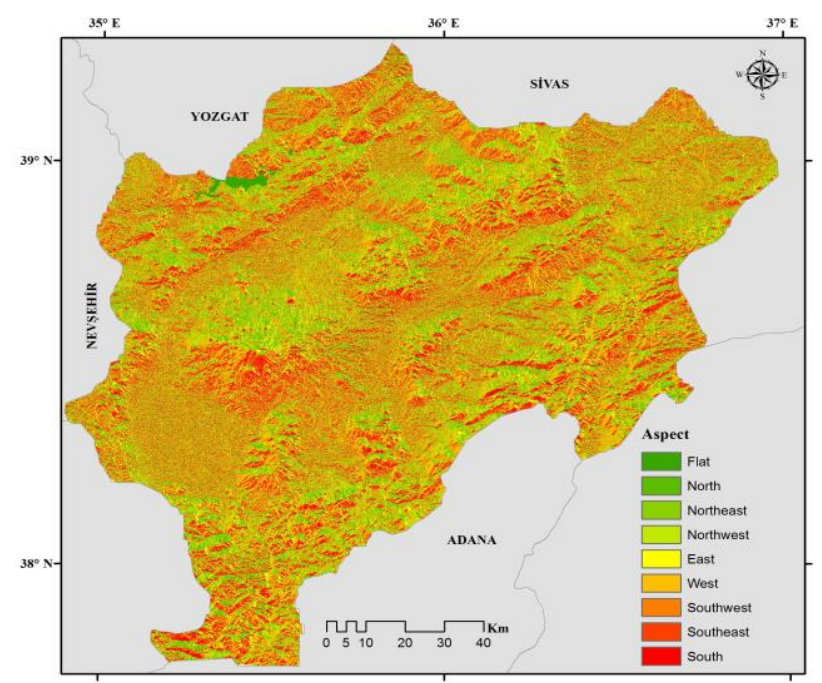

Figure 4. Reclassified aspect map

\subsubsection{Slope}

Another important criterion used to prevent high installation costs is slope. Slope, is indispensable for Geomatics applications. Since landslides generally occur in high slope areas, $0-4 \%$ slope is more convenient to ensure the safety of solar PV power plants. In addition, regions that are extremely inclined and difficult to walk often increase investment costs (Hafeznia et al., 2017; Solangi et al., 2019). The slope map produced from the DEM map has 30 x $30 \mathrm{~m}$ spatial resolution, like the aspect map. The low slope area (i.e., 0-1\%) corresponds to the Yamula Dam Lake, as in the aspect map (i.e., non-useful area). The reclassified slope map is presented in Figure 5.

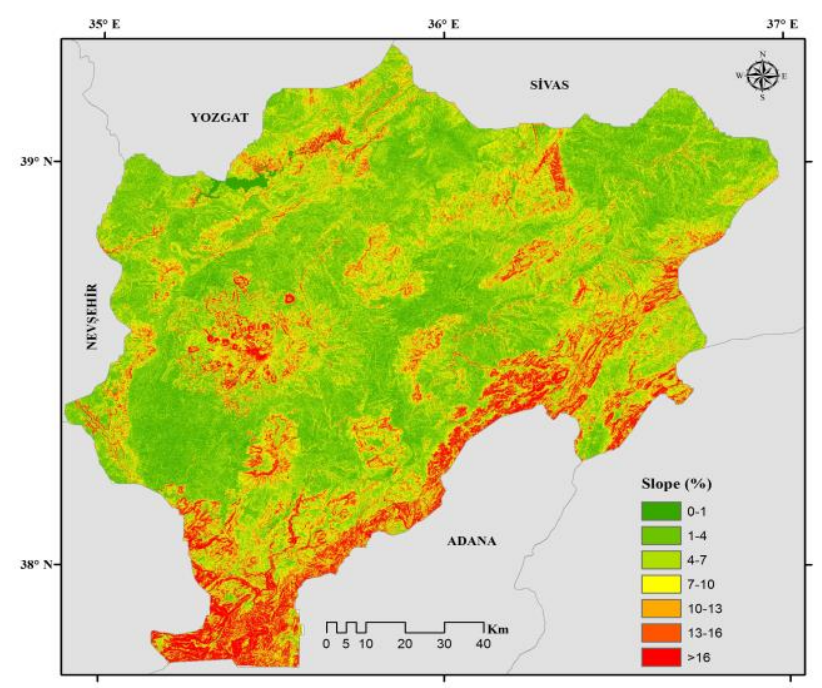

Figure 5. Reclassified slope map 


\subsubsection{Land Use / Cover}

Land use / cover types are very important in city planner and Geomatics applications. City growth areas, industrial areas, agricultural areas, etc., are usually planned to depend on land use / cover types. Using local land use / cover types are a difficult and troublesome process. In solar PV power plant installation, the land cover types are a decisive criterion for defining constraints and site selection. For this reason, land use / cover databases that were globally prepared are frequently preferred by researchers (Colak et al., 2020; Doljak and Stanojević, 2017). In this study, the dataset obtained from the Coordination of Information on the Environment (CORINE) database was used. The criteria in (Tercan et al., 2020) was taken into account for the classification of land use / cover types obtained from the CORINE database and for determining non-useful areas. The CORINE ID descriptions shown in Figure 6 are as follows: Mineral extraction sites (131), Construction sites (133), Non-irrigated arable land (211), Permanently irrigated land (212),Vineyards (221), Fruit trees and berry plantations (222), Pastures (231), Complex cultivation patterns (242), Land principally occupied by agriculture, with significant areas of natural vegetation (243), Natural grasslands (321), Sclerophyllous vegetation (323), Transitional woodland-shrub (324), Bare rocks (332), Sparsely vegetated areas (333), Inland marshes (411), and Salt marshes (421).

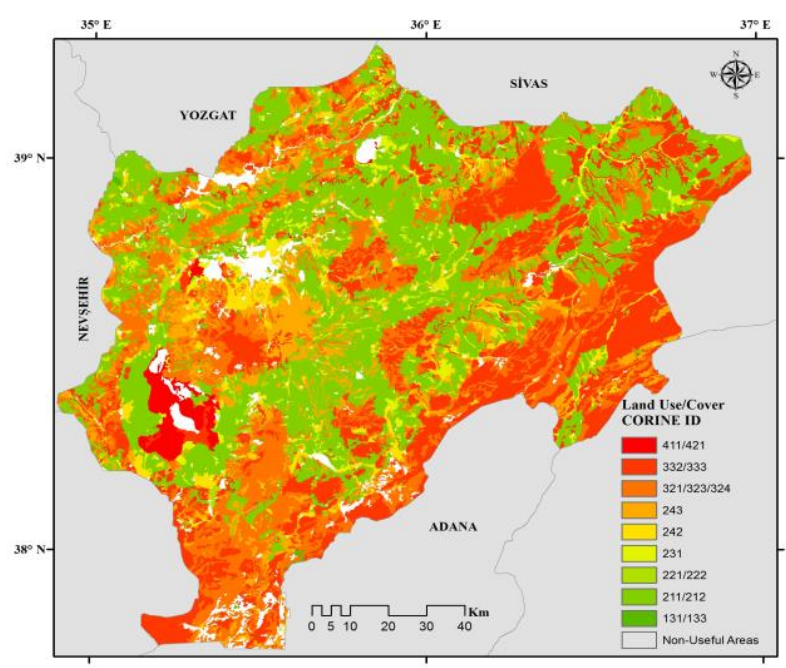

Figure 6. Reclassified land use/cover map 


\subsubsection{Distance from bird migration routes}

The Sultan Sazlığı wetland in Kayseri is home to many bird species. Birds migrate through Kayseri at different times of the year. In order to eliminate the risk of birds changing routes due to the reflected sunlight from the solar PV power plants, it is necessary to install them at a certain distance from the bird migration routes. It was also taken into account that the birds would reduce efficiency by contaminating the solar PV power plants during migration. Bird migration route data was provided from the Kayseri Provincial Directorate of Agriculture and Forestry. The reclassified distance from bird migration routes map is presented in Figure 7.

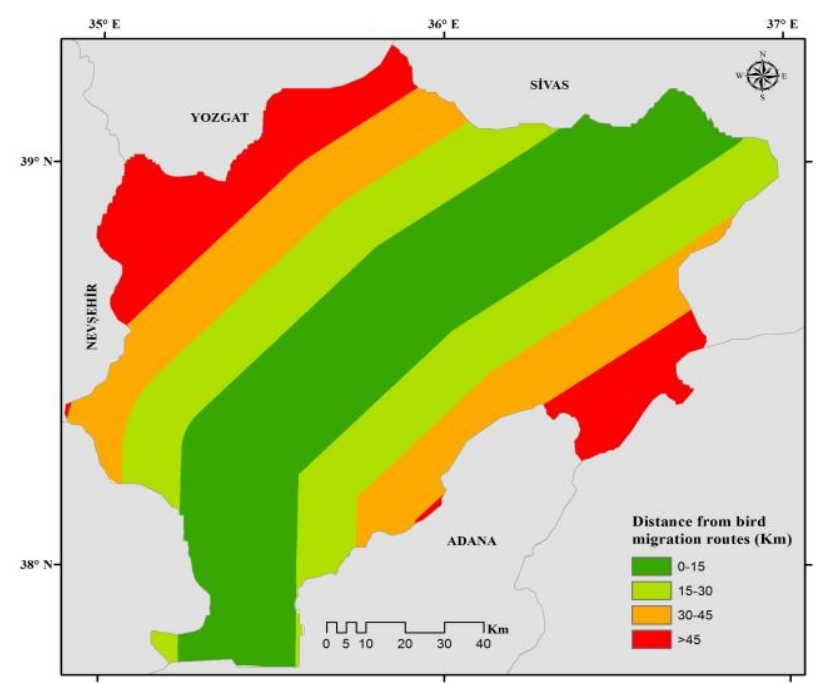

Figure 7. Reclassified distance from bird migration routes map

\subsubsection{Geomorphological \& Hydrological conditions}

\subsubsection{Distance from faults}

In countries such as Turkey, which is located in an earthquake zone, distance from fault criteria should be taken into consideration. PV power plants close to a fault line will be seriously affected and lose their functionality as they have a rigid structure after an earthquake. Therefore, a distance from fault map was produced, based on expert opinions with multiple buffer analysis. The distance from fault map, which was reclassified according to the distances determined considering the earthquake zones close to Kayseri, is in Figure 8. The fault vector data is 
downloaded from General Directorate of Mineral Research And Explorations internet site (URL-2, Last Access: 22/07/2020).

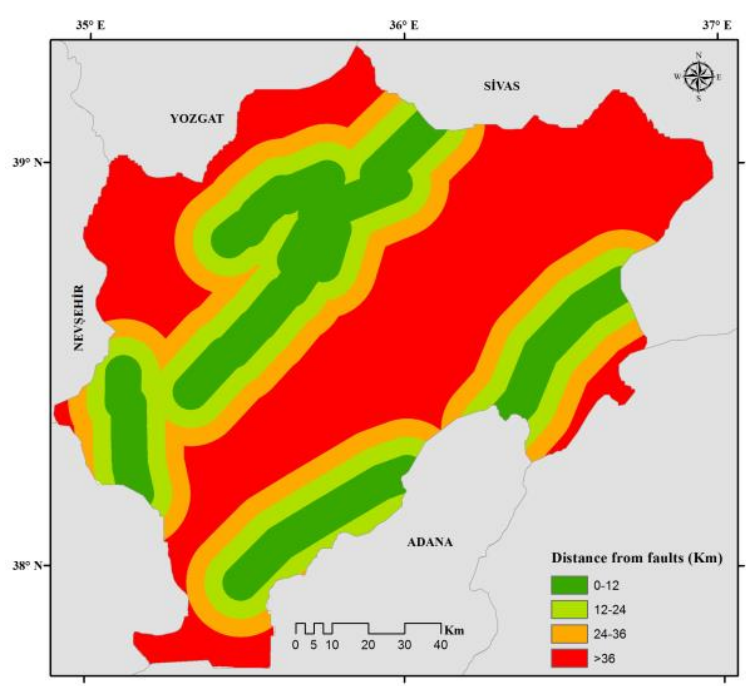

Figure 8. Reclassified distance from faults map

\subsubsection{Distance from rivers and water surfaces}

Solar PV power plants should not be built near water structures in order to protect the ecological environment and nature. However, panels contaminated by various substances (i.e., dust, mud, feces) must be cleaned sometimes. Panels that are not clean enough do not provide full performance and reduce efficiency. Since the possibility of obtaining water by drilling is not always possible at the sites where solar PV power plants are installed, the proximity to water resources is very important. In this study, two sources of water, river and water surfaces (i.e., dam, pond, lake), were used as criteria. Related data was taken from the Provincial Directorate of Environment and Urbanization of Kayseri Governorship. The reclassified distance from water surface and rivers maps is presented in Figure 9. 


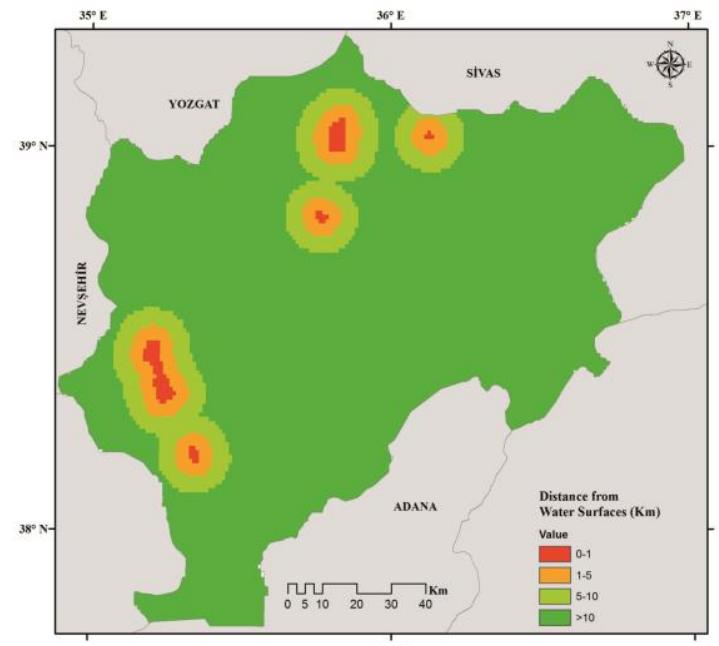

(a)

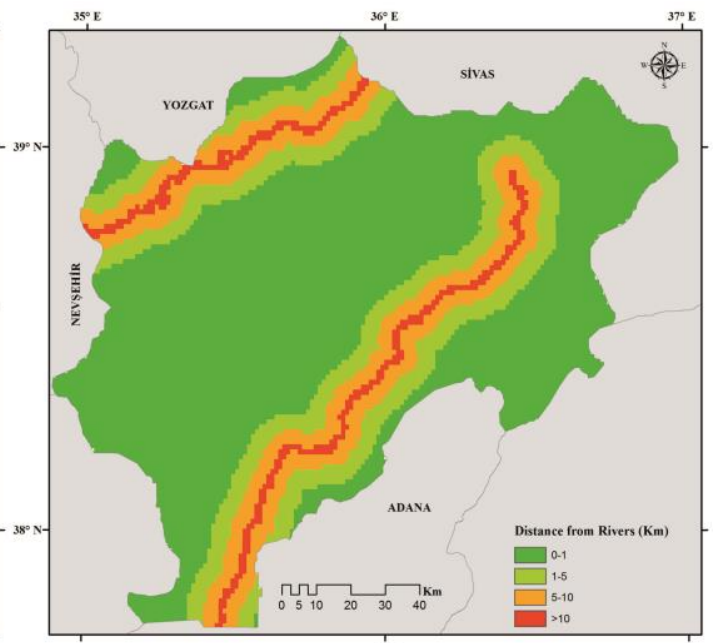

(b)

Figure 9. Reclassified distance from a) water surface and b) rivers maps

\subsubsection{Infrastructural / Superstructure Features}

\subsubsection{Distance from power lines and transformer centers}

Transmission and distribution of electricity with minimal loss is very important. Existing structures can generally be considered safe and risk-free. Places where solar PV power plants are installed may not always be suitable for power line and transformer installation. Therefore, the construction of solar PV power plants near power lines reduces losses in transmission lines and increases reliability. It is important to use existing lines effectively, since installing a new line requires additional costs. In addition, the fact that electricity produced by solar PV power plants is close to a transformer center reduces the cost as it prevents the construction of new transformers (Koc et al., 2019). Line and point data of power line and transformer centers were taken from Kayseri and its surrounding electric distribution company. The reclassified distance from power line and transformer center maps are presented in Figure 10. 


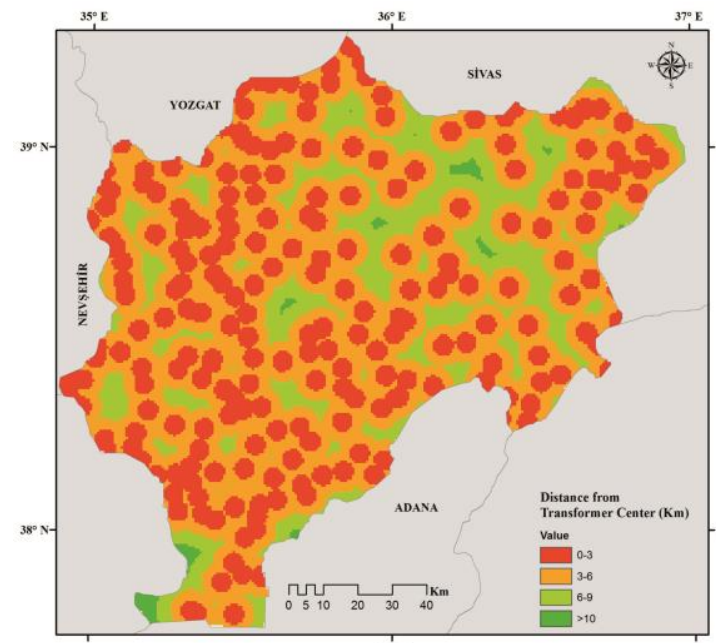

(a)

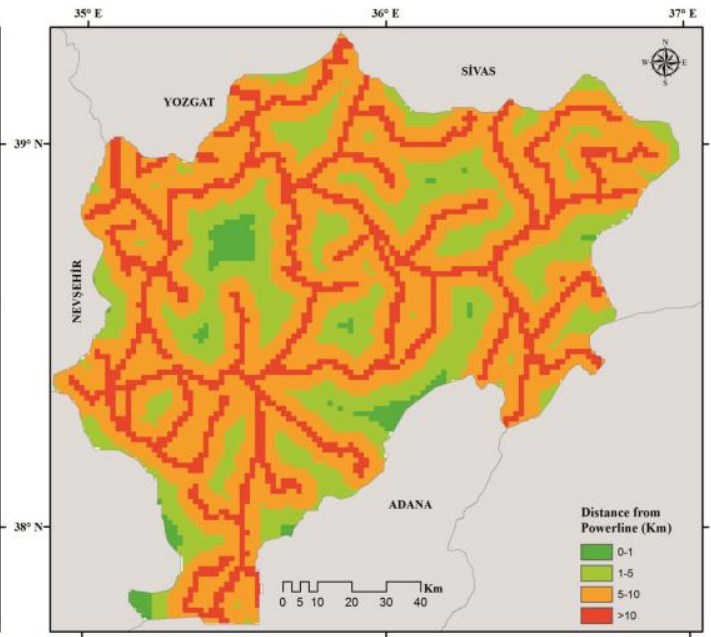

(b)

Figure 10. Reclassified distance from power line and transformer center maps

\subsubsection{Distance from road and railway transportation networks}

Transportation networks have a great influence on the installation of industrial structures. It is very difficult to build solar PV power plants in inaccessible areas. Even if they are not built on the main roadside, solar PV power plant mounting is possible with the help of new side roads, which are opened from main roads. In addition, proximity to the road is important for transporting people, who will ensure the safety and maintenance of the solar PV power plants. Since the railway passes through places where there are no roads, equipment supply can also be provided by railway (Hafeznia et al., 2017; Tercan et al., 2020). Kayseri transportation networks in the middle of Turkey's transportation network are well developed. Kayseri road transportation data was taken from the $6^{\text {th }}$ Regional Directorate of Highways and railway data was taken from the Provincial Directorate of Environment and Urbanization of Kayseri Governorship. The reclassified distance from road and railway transportation networks map is presented in Figure 11. 


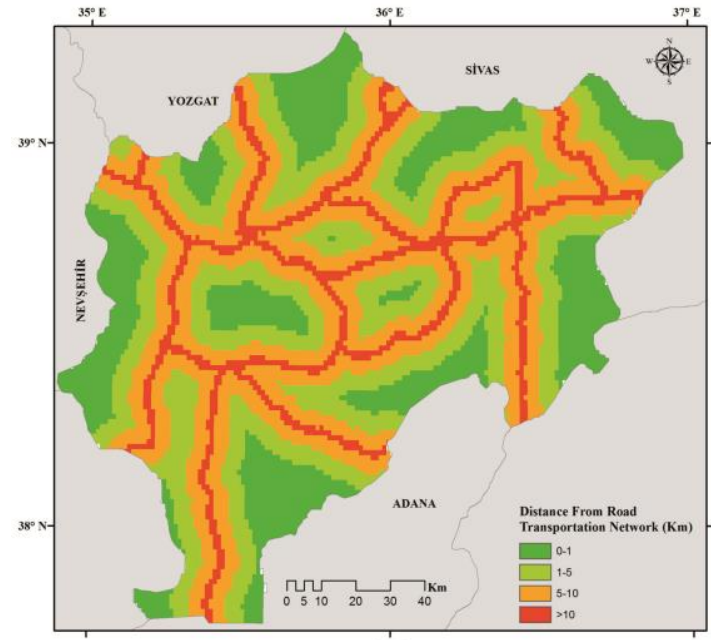

(a)

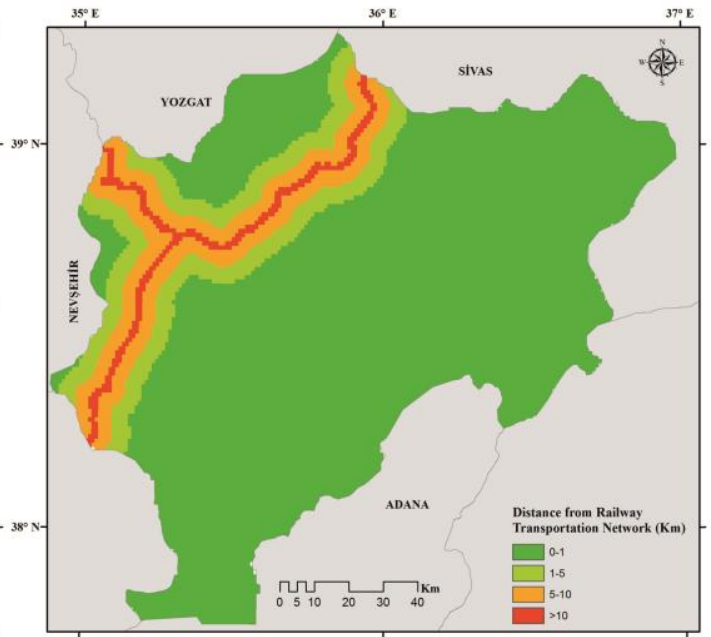

(b)

Figure 11. Reclassified distance from road and railway transportation networks map

\section{Results and Discussion}

In this paper, GIS-based MCDM methods were compared for selection of the most suitable sites for solar PV power plants in Kayseri. Furthermore, this study helps decision makers to implement a spatial decision-making process and to analyze the results obtained by the combination of GIS tools and MCDM methods. In rank-based methods, the weight of the criteria is determined by rank, while in the AHP method it is determined by a pairwise comparison matrix. The calculated weights of the main and sub-criteria and the consistency results obtained with AHP are presented in Table 3 and Table 4, respectively.

Table 3. Calculated weights of main criteria with Rank-based and AHP methods.

\begin{tabular}{|l|l|l|l|l|l|l|l|}
\hline \multicolumn{1}{|c|}{ Main-Criteria } & \multicolumn{2}{|c|}{ RS } & \multicolumn{2}{c|}{ RR } & \multicolumn{1}{c|}{ ROC } & \multicolumn{3}{c|}{ AHP } \\
\cline { 2 - 6 } & \multicolumn{3}{|c|}{$w$} & $w$ & CR (\%) & CI \\
\hline Topographical and basic conditions & 0.500 & 0.545 & 0.611 & 0.714 & 0 & $2.22 \mathrm{E}^{-16}$ \\
\hline $\begin{array}{l}\text { Geomorphological \& Hydrological } \\
\text { conditions }\end{array}$ & 0.25 & 0.228 & 0.195 & 0.143 & & \\
\cline { 1 - 5 } Infrastructural/Superstructure Features & 0.25 & 0.227 & 0.194 & 0.143 & & \\
\hline
\end{tabular}

When Table 3 is examined, it is seen that the highest weight for MCDM methods is allocated to topographical and basic conditions. The AHP method produced quite consistent results $(\mathrm{CR}=0)$. Although the infrastructural / superstructure features contain very important subcriteria in terms of solar PV power plant installation, minimum weight was allocated, as special 
structures for power plants can be built later. The main criteria produced different numerical values but the weights are in the same order for the four MCDM methods. The most suitable site selection maps for the solar PV power plant according to the calculated weights, with four MCDM methods, are presented in Figure 12. Reclassified maps were created by passing through two stages. A weighted layer map was created by using GIS tools according to the weight of the indicators calculated from MCDM methods. Later, depending on the sub and main criteria weights, suitability maps were created from the weighted sum of the related layers. The created maps are different from each other because each MCDM yields different weight to the indicators, sub, and main criteria. Suitability maps created with MCDM methods consist of pixels of different amplitude. In order to make quantitative and qualitative comparisons, it is necessary to reclassify pixels of different priority with a logical reclassification method. Although different methods (i.e., standard deviation, equal interval, natural breaks, etc.) have been developed for the reclassification process in GIS tools, the most suitable method for the study area is the quartile. The suitability maps were divided into 5 levels. Maps were reclassified as poor site ( $1^{\text {st }}$ quartile $)$, low site $\left(3^{\text {rd }}\right.$ quartile $)$, fair site $\left(5^{\text {th }}\right.$ quartile $)$, good site $\left(7^{\text {th }}\right.$ quartile), and excellent site ( $9^{\text {th }}$ quartile). Additionally, the classification distribution of the suitable areas related to each class of excellent, good, fair, low, poor, and non-useful area is given in Table 5. 
Table 4. Calculated weights of sub-criteria with Rank-based and AHP methods.

\begin{tabular}{|c|c|c|c|c|c|c|c|c|c|c|c|c|c|}
\hline \multirow[t]{2}{*}{ Sub-Criteria } & $\mathbf{R S}$ & $\mathbf{R R}$ & ROC & \multicolumn{3}{|c|}{ AHP } & \multirow[b]{2}{*}{ Indicators } & $\mathbf{R S}$ & $\mathbf{R R}$ & ROC & \multicolumn{3}{|c|}{ AHP } \\
\hline & \multicolumn{3}{|c|}{$w$} & $w$ & $\begin{array}{l}\mathrm{CR} \\
(\%)\end{array}$ & $\mathrm{CI}$ & & & $w$ & & $w$ & $\begin{array}{l}\mathrm{CR} \\
(\%)\end{array}$ & $\mathrm{CI}$ \\
\hline \multirow{6}{*}{$\begin{array}{l}\text { Global } \\
\text { Horizontal } \\
\text { Irradiation } \\
(\mathrm{GHI}) \\
\left(\mathrm{kWh} / \mathrm{m}^{2}\right)\end{array}$} & \multirow[t]{6}{*}{0.333} & \multirow[t]{6}{*}{0.438} & \multirow[t]{6}{*}{0.457} & \multirow[t]{6}{*}{0.447} & 9.5 & 0.087 & $808-1500$ & 0.048 & 0.068 & 0.028 & 0.025 & 8.1 & 0.101 \\
\hline & & & & & & & $1500-1650$ & 0.095 & 0.082 & 0.061 & 0.045 & & \\
\hline & & & & & & & $1650-1700$ & 0.143 & 0.102 & 0.103 & 0.082 & & \\
\hline & & & & & & & $1700-1750$ & 0.190 & 0.136 & 0.158 & 0.149 & & \\
\hline & & & & & & & $1750-1800$ & 0.238 & 0.204 & 0.242 & 0.254 & & \\
\hline & & & & & & & $1800-1830$ & 0.286 & 0.408 & 0.408 & 0.445 & & \\
\hline Aspect & 0.233 & 0.182 & 0.207 & 0.177 & & & North & 0.044 & 0.044 & 0.026 & 0.019 & 5.0 & 0.075 \\
\hline & & & & & & & East & 0.111 & 0.071 & 0.083 & 0.090 & & \\
\hline & & & & & & & West & 0.133 & 0.088 & 0.111 & 0.105 & & \\
\hline & & & & & & & South & 0.200 & 0.353 & 0.314 & 0.309 & & \\
\hline & & & & & & & Northeast & 0.067 & 0.050 & 0.042 & 0.037 & & \\
\hline & & & & & & & Northwest & 0.089 & 0.059 & 0.061 & 0.052 & & \\
\hline & & & & & & & Southeast & 0.178 & 0.177 & 0.203 & 0.196 & & \\
\hline & & & & & & & Southwest & 0.156 & 0.118 & 0.148 & 0.163 & & \\
\hline & & & & & & & Flat & 0.022 & 0.039 & 0.012 & 0.028 & & \\
\hline Slope (\%) & 0.167 & 0.128 & 0.098 & 0.212 & & & $0-1$ & 0.250 & 0.386 & 0.370 & 0.355 & 2.0 & 0.026 \\
\hline & & & & & & & $1-4$ & 0.214 & 0.193 & 0.228 & 0.235 & & \\
\hline & & & & & & & $4-7$ & 0.179 & 0.129 & 0.156 & 0.165 & & \\
\hline & & & & & & & $7-10$ & 0.143 & 0.096 & 0.109 & 0.103 & & \\
\hline & & & & & & & $10-13$ & 0.107 & 0.077 & 0.073 & 0.070 & & \\
\hline & & & & & & & $13-16$ & 0.071 & 0.064 & 0.044 & 0.042 & & \\
\hline & & & & & & & $>16$ & 0.036 & 0.055 & 0.020 & 0.030 & & \\
\hline Land & 0.200 & 0.164 & 0.148 & 0.128 & & & 131,133 & 0.144 & 0.150 & 0.155 & 0.038 & 5.4 & 0.079 \\
\hline Use/Cover & & & & & & & 211,212 & 0.039 & 0.043 & 0.023 & 0.020 & & \\
\hline (CORINE ID) & & & & & & & 221,222 & 0.050 & 0.047 & 0.031 & 0.037 & & \\
\hline & & & & & & & 231 & 0.106 & 0.074 & 0.082 & 0.070 & & \\
\hline & & & & & & & 242 & 0.078 & 0.056 & 0.052 & 0.155 & & \\
\hline & & & & & & & 243 & 0.144 & 0.103 & 0.129 & 0.138 & & \\
\hline & & & & & & & $\begin{array}{l}321, \quad 323, \\
324\end{array}$ & 0.144 & 0.144 & 0.159 & 0.251 & & \\
\hline & & & & & & & 332,333 & 0.194 & 0.309 & 0.287 & 0.199 & & \\
\hline & & & & & & & 411,421 & 0.100 & 0.075 & 0.081 & 0.092 & & \\
\hline Distance from & 0.067 & 0.088 & 0.090 & 0.036 & & & $0-15$ & 0.400 & 0.480 & 0.521 & 0.508 & 7.3 & 0.066 \\
\hline bird migration & & & & & & & $15-30$ & 0.300 & 0.240 & 0.271 & 0.265 & & \\
\hline routes & & & & & & & $30-45$ & 0.200 & 0.160 & 0.146 & 0.151 & & \\
\hline & & & & & & & $>45$ & 0.100 & 0.120 & 0.063 & 0.075 & & \\
\hline Distance from & & & & 0.114 & 3 & 0.015 & $0-12$ & 0.100 & 0.120 & 0.063 & 0.049 & 8.8 & 0.080 \\
\hline faults $(\mathrm{km})$ & & & & & & & $12-24$ & 0.200 & 0.160 & 0.146 & 0.136 & & \\
\hline & & & & & & & $24-36$ & 0.300 & 0.240 & 0.271 & 0.259 & & \\
\hline & & & & & & & $>36$ & 0.400 & 0.480 & 0.521 & 0.556 & & \\
\hline Distance from & & & & 0.481 & & & $0-1$ & 0.400 & 0.480 & 0.521 & 0.556 & 8.8 & 0.080 \\
\hline rivers & & & & & & & $1-5$ & 0.300 & 0.240 & 0.271 & 0.259 & & \\
\hline & & & & & & & $5-10$ & 0.200 & 0.160 & 0.146 & 0.136 & & \\
\hline & & & & & & & $>10$ & 0.100 & 0.120 & 0.063 & 0.049 & & \\
\hline Distance From & 0.417 & 0.455 & 0.486 & 0.405 & & & $0-1$ & 0.400 & 0.480 & 0.063 & 0.049 & 8.8 & 0.080 \\
\hline Water & & & & & & & $1-5$ & 0.300 & 0.240 & 0.146 & 0.136 & & \\
\hline Surfaces & & & & & & & $5-10$ & 0.200 & 0.160 & 0.271 & 0.259 & & \\
\hline & & & & & & & $>10$ & 0.100 & 0.120 & 0.521 & 0.556 & & \\
\hline Distance From & 0.400 & 0.480 & 0.521 & 0.388 & 1.6 & 0.634 & $0-1$ & 0.400 & 0.480 & 0.521 & 0.556 & 8.8 & 0.080 \\
\hline Power line & & & & & & & $1-5$ & 0.300 & 0.240 & 0.271 & 0.259 & & \\
\hline$(\mathrm{km})$ & & & & & & & $5-10$ & 0.200 & 0.160 & 0.146 & 0.136 & & \\
\hline & & & & & & & $>10$ & 0.100 & 0.120 & 0.063 & 0.049 & & \\
\hline Distance From & 0.225 & 0.180 & 0.177 & 0.181 & & & $0-1$ & 0.400 & 0.480 & 0.521 & 0.556 & 8.8 & 0.080 \\
\hline Road & & & & & & & $1-5$ & 0.300 & 0.240 & 0.271 & 0.259 & & \\
\hline Transportation & & & & & & & $5-10$ & 0.200 & 0.160 & 0.146 & 0.136 & & \\
\hline Network (km) & & & & & & & $>10$ & 0.100 & 0.120 & 0.063 & 0.049 & & \\
\hline Distance From & 0.100 & 0.120 & 0.063 & 0.231 & & & $0-1$ & 0.400 & 0.480 & 0.521 & 0.556 & 8.8 & 0.080 \\
\hline Railway & & & & & & & $1-5$ & 0.300 & 0.240 & 0.271 & 0.259 & & \\
\hline Transportation & & & & & & & $5-10$ & 0.200 & 0.160 & 0.146 & 0.136 & & \\
\hline Network (km) & & & & & & & $>10$ & 0.100 & 0.120 & 0.063 & 0.049 & & \\
\hline Distance from & 0.275 & 0.220 & 0.240 & 0.199 & & & $0-3$ & 0.400 & 0.480 & 0.521 & 0.556 & 8.8 & 0.080 \\
\hline transformer & & & & & & & $3-6$ & 0.300 & 0.240 & 0.271 & 0.259 & & \\
\hline center $(\mathrm{km})$ & & & & & & & $6-10$ & 0.200 & 0.160 & 0.146 & 0.136 & & \\
\hline & & & & & & & $>10$ & 0.100 & 0.120 & 0.063 & 0.049 & & \\
\hline
\end{tabular}


In all four MCDM methods, the Yahyalı district, located in the south, Mount Erciyes, located the center, and its surroundings were obtained as poor sites. The region where the districts join, Develi, located in south, and Yeşilhisar, located in the southwest, is the most excellent site. The Akkışla and Bünyan districts, located in the north, were generally calculated as low site and fair site, respectively. Good sites generally occurred around the Pınarbaşı district, located in the east of Kayseri. There are different levels of suitable criteria in the Incesu district, located in the west, where most solar PV power plants are located. The border areas of Kayseri, towards Adana and Sivas provinces were generally calculated as poor and low sites. The Sariz and Tomarza districts, located in the east, which have few installed solar PV power plants, may be new locations for stakeholders. The districts are considered suitable for investment, since the land prices are low, and the calculated suitability map is generally classified as good and excellent sites.

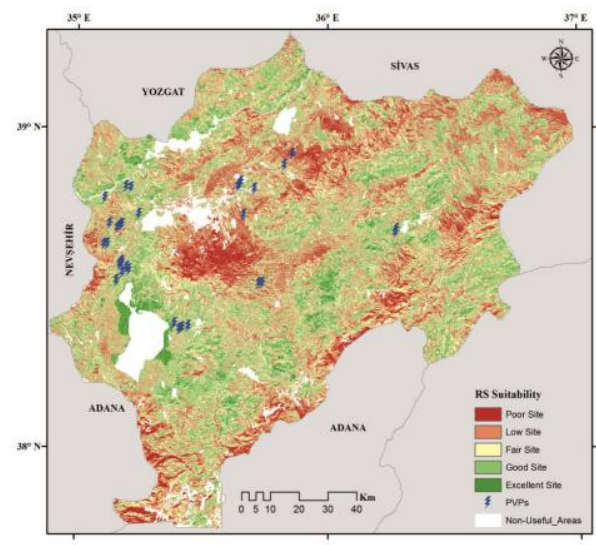

(a)

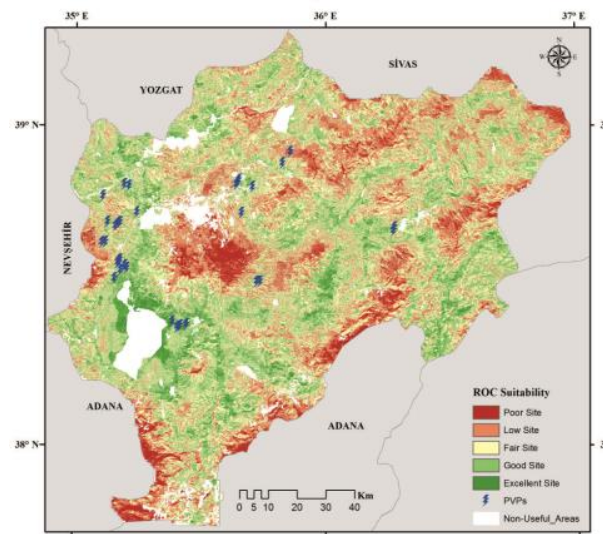

(c)

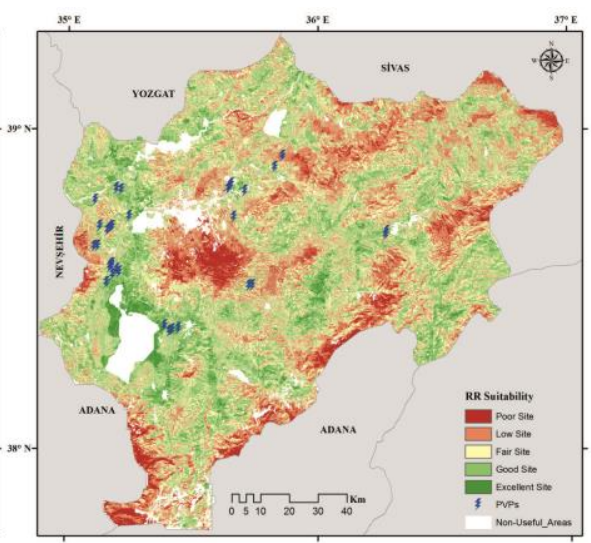

(b)

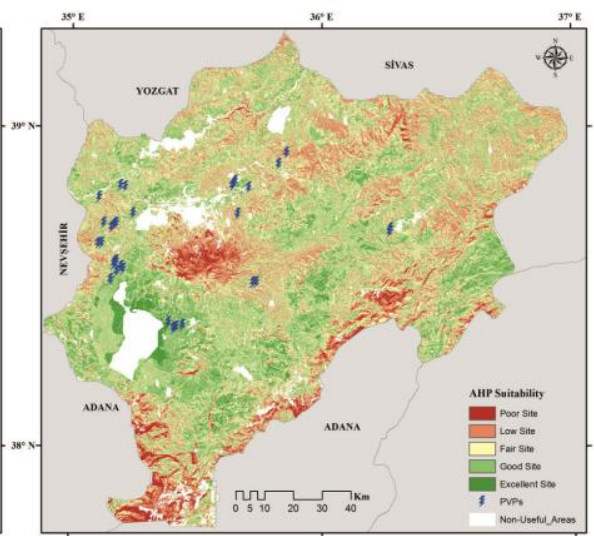

(d)

Figure 12. Suitability map calculated from a) RS, b) RR, c) ROC, and d) AHP 
When Figure 12 and Table 5 are examined, the map created with the AHP method produced more optimistic results compared to the rank-based methods because low sites are less than in other methods. In general, there are not many excellent and poor sites in the results obtained by the four methods, while fair sites are more common. The AHP method allocated more weight to GHI than other methods. In addition, in the weight ranking of the sub-criteria of topographical and basic conditions, the slope had more weight than the aspect. The sub-criteria of infrastructural / superstructure features are more consistent than others are because the decision-makers did not have much difficulty in creating the relevant sub-criteria $(\mathrm{CR}=1.6)$. Distances from bird migration routes are indispensable criteria in Kayseri, which hosts a wide range of birds. The reason for the importance of distance from fault is less than the distance from river and distance from water surfaces criteria is that Kayseri is not located in a $1^{\text {st }}$ degree earthquake zone. The low significance of this sub-criterion in pairwise comparison with other criteria caused its low weight. The reason for the high CR value is that the level of importance between the methods cannot be determined well enough. The biggest difference between the methods can be seen in the weighting of land use / cover. In this criterion, since each method produces different weights for the indicators, the reclassified maps differ. It should be noted that since most of the data used for Kayseri has dynamic structure, it could change over time.

Table 5. Area classification distribution of the suitable site

\begin{tabular}{|c|c|c|c|c|c|c|c|}
\hline & \multicolumn{6}{|c|}{ Convenience Index } \\
\hline & & $\begin{array}{c}\text { Poor Site } \\
(\%)\end{array}$ & $\begin{array}{c}\text { Low Site } \\
(\%)\end{array}$ & Fair Site (\%) & $\begin{array}{c}\text { Good Site } \\
(\%)\end{array}$ & $\begin{array}{c}\text { Excellent Site } \\
(\%)\end{array}$ & $\begin{array}{c}\text { Non-Useful Areas } \\
(\%)\end{array}$ \\
\hline \multirow{4}{*}{$\begin{array}{l}\frac{0}{\delta} \\
\frac{0}{0} \\
\sum\end{array}$} & $\mathrm{RS}$ & 8.53 & 25.36 & 31.45 & 22.35 & 2.89 & 9.43 \\
\hline & RR & 6.10 & 23.19 & 32.89 & 25.57 & 2.79 & 9.43 \\
\hline & $\mathrm{ROC}$ & 6.19 & 22.69 & 33.78 & 24.59 & 3.32 & 9.43 \\
\hline & AHP & 3.59 & 19.48 & 35.18 & 28.75 & 3.56 & 9.43 \\
\hline
\end{tabular}

In this paper, 33 randomly selected PV power plants, which were considered to be installed on an excellent site, were used for the validation of MCDM methods. When the suitability maps are examined, it is seen that many of the installed solar PV power plants were established on 
excellent, good, and fair sites. The spatial positions of the relevant solar PV power plants are shown in Figure 12. The distribution of solar PV power plants on the suitability maps are given in Table 6.

Table 6. Distribution of PV power plants according to suitable level

\begin{tabular}{|c|c|c|c|c|c|c|c|}
\hline \multicolumn{2}{|c|}{} & \multicolumn{7}{|c|}{ Convenience Index } \\
\cline { 2 - 8 } \multicolumn{2}{|c|}{} & $\begin{array}{c}\text { Poor Site } \\
(\%)\end{array}$ & $\begin{array}{c}\text { Low Site } \\
(\%)\end{array}$ & $\begin{array}{c}\text { Fair Site } \\
(\%)\end{array}$ & $\begin{array}{c}\text { Good Site } \\
(\%)\end{array}$ & $\begin{array}{c}\text { Excellent Site } \\
(\%)\end{array}$ & $\begin{array}{c}\text { Non-Useful Areas } \\
(\%)\end{array}$ \\
\hline \multirow{2}{*}{$\approx$} & RS & $1(3.03)$ & $5(15.15)$ & $9(27.27)$ & $14(42.42)$ & $4(12.12)$ & $0(0)$ \\
\cline { 2 - 8 } & RR & $1(3.03)$ & $3(9.09)$ & $6(18.18)$ & $17(51.52)$ & $6(18.18)$ & $0(0)$ \\
\cline { 2 - 8 } & ROC & $1(3.03)$ & $4(12.12)$ & $5(15.15)$ & $19(57.58)$ & $4(12.12)$ & $0(0)$ \\
\cline { 2 - 8 } & AHP & $0(0)$ & $4(12.12)$ & $7(21.21)$ & $17(51.52)$ & $5(15.15)$ & $0(0)$ \\
\hline
\end{tabular}

Table 6 shows that no PV power plant is built in a non-useful area. In general, it is observed that all methods produce consistent results. Most of the excellent sites available on the map were produced by the RR method. In addition, none of the solar PV power plants is included in a poor site on the map produced by the AHP method.

\section{Conclusion}

The aim of this study was combining GIS tools with MCDM methods to investigate the most suitable solar PV power plant site for Kayseri. For this, rank based methods (rank sum, rank reciprocal weights, and rank order centroid weights) and the AHP method were used. In many stages, GIS tools provided great benefits and advantages to the decision makers. Namely, nonuseful areas were defined and stacked with GIS tools and were excluded from the functional areas Thus, transactions were carried out quickly and effectively. Suitability maps were created using the weights obtained from the MCDM methods. The 3 main criteria (topographical and basic conditions, geomorphological \& hydrological conditions, and infrastructural / superstructure features) and 12 sub-criteria (global horizontal irradiation, aspect, slope, land use / cover, bird migration route, faults, rivers, water surfaces, power lines, road transportation network, railway transportation network, and transformer centers) were selected according to two experts' opinions and previous studies. Criteria and limits should be selected specifically 
for a study area. In order to interpret the created map quantitatively and qualitatively, the levels of suitability were determined by reclassifying in five classes (excellent, good, fair, low, poor site). For detailed comparison, the level at which the installed solar PV power plants correspond on the result maps were examined. Rank based methods provided more flexibility and facility to decision makers than the AHP method did. When 33 randomly selected existing PV power plants and distribution of the suitable sites ( $3.56 \%$ for excellent site and $28.75 \%$ for good site) were examined, it can be said that the AHP method produced optimistic results because there were no plants in the poor sites on the suitability map. Considering that, the existing solar PV power plants are on the excellent site, it is seen that the RR method yields the best results. In general, topographical and basic conditions took the highest weight value among the main criteria, while geomorphological \& hydrological conditions and infrastructural / superstructure features took equal weights. Among the sub-criteria, GHI was the most effective criterion, while distance from bird migration routes was the weakest. In addition, the Sarız and Tomarza districts, located in the east, and Incesu district, located in the west, were determined as the most suitable sites for stakeholders by four methods.

In future studies, the GIS based MCDM methods for the most suitable site selection in Kayseri and surrounding province will be investigated. For this, the efficiency of the existing PV power stations with in-situ observations will be examined and the results will be compared more fairly.

\section{Compliance with ethical standards}

Conflict of Interest Author states that there is no conflict of interest. 


\section{References}

Al Garni, H.Z., Awasthi, A., 2017. Solar PV power plant site selection using a GIS-AHP based approach with application in Saudi Arabia. Applied Energy 206, 1225-1240.

Ali, S.A., Parvin, F., Al-Ansari, N., Pham, Q.B., Ahmad, A., Raj, M.S., Anh, D.T.J.E.S., Research, P., 2020. Sanitary landfill site selection by integrating AHP and FTOPSIS with GIS: a case study of Memari Municipality, India. 1-23.

Aragonés-Beltrán, P., Chaparro-González, F., Pastor-Ferrando, J.-P., Pla-Rubio, A., 2014. An AHP (Analytic Hierarchy Process)/ANP (Analytic Network Process)-based multi-criteria decision approach for the selection of solar-thermal power plant investment projects. Energy 66, 222-238.

Aydin, N.Y., Kentel, E., Duzgun, H.S., 2013. GIS-based site selection methodology for hybrid renewable energy systems: A case study from western Turkey. Energy conversion and management 70, 90-106.

Barron, F.H., Barrett, B.E., 1996. Decision quality using ranked attribute weights. Management science 42(11), 1515-1523.

Choi, Y., Suh, J., Kim, S.-M., 2019. GIS-based solar radiation mapping, site evaluation, and potential assessment: A review. Applied Sciences 9(9), 1960.

Colak, H.E., Memisoglu, T., Gercek, Y., 2020. Optimal site selection for solar photovoltaic (PV) power plants using GIS and AHP: A case study of Malatya Province, Turkey. Renewable Energy 149, 565-576.

Doljak, D., Stanojević, G., 2017. Evaluation of natural conditions for site selection of groundmounted photovoltaic power plants in Serbia. Energy 127, 291-300.

Georgiou, A.G., Skarlatos, D., 2016. Optimal site selection for sitting a solar park using multicriteria decision analysis and geographical information systems.

Hafeznia, H., Yousefi, H., Astaraei, F.R., 2017. A novel framework for the potential assessment of utility-scale photovoltaic solar energy, application to eastern Iran. Energy Conversion and Management 151, 240-258.

Hashemizadeh, A., Ju, Y., Dong, P., 2019. A combined geographical information system and Best-Worst Method approach for site selection for photovoltaic power plant projects. International Journal of Environmental Science and Technology, 1-16.

Kamdar, I., Ali, S., Bennui, A., Techato, K., Jutidamrongphan, W.J.R., Conservation, Recycling, 2019. Municipal solid waste landfill siting using an integrated GIS-AHP approach: A case study from Songkhla, Thailand. 149, 220-235.

Koc, A., Turk, S., Şahin, G., 2019. Multi-criteria of wind-solar site selection problem using a GIS-AHP-based approach with an application in Igdir Province/Turkey. Environmental Science and Pollution Research 26(31), 32298-32310.

Rediske, G., Siluk, J.C.M., Michels, L., Rigo, P.D., Rosa, C.B., Cugler, G., 2020. Multi-criteria decision-making model for assessment of large photovoltaic farms in Brazil. Energy 197, 117167.

Renewables, I., 2017. Analysis and forecasts to 2022-executive summary. tech. rep., International Energy Agency.

Richter, A., Ng, K.T.W., Karimi, N.J.R., Conservation, Recycling, 2019. A data driven technique applying GIS, and remote sensing to rank locations for waste disposal site expansion. $149,352-362$.

Saaty, T.L., 2008. Decision making with the analytic hierarchy process. International journal of services sciences 1(1), 83-98.

Sánchez-Lozano, J.M., Antunes, C.H., García-Cascales, M.S., Dias, L.C., 2014. GIS-based photovoltaic solar farms site selection using ELECTRE-TRI: Evaluating the case for Torre Pacheco, Murcia, Southeast of Spain. Renewable Energy 66, 478-494. 
Sánchez-Lozano, J.M., Teruel-Solano, J., Soto-Elvira, P.L., García-Cascales, M.S., 2013. Geographical Information Systems (GIS) and Multi-Criteria Decision Making (MCDM) methods for the evaluation of solar farms locations: Case study in south-eastern Spain. Renewable and sustainable energy reviews 24, 544-556.

Schlecht, M., Meyer, R., 2012. Site selection and feasibility analysis for concentrating solar power (CSP) systems, Concentrating Solar Power Technology. Elsevier, pp. 91-119.

Shorabeh, S.N., Firozjaei, M.K., Nematollahi, O., Firozjaei, H.K., Jelokhani-Niaraki, M., 2019. A risk-based multi-criteria spatial decision analysis for solar power plant site selection in different climates: A case study in Iran. Renewable Energy 143, 958-973.

Solangi, Y.A., Shah, S.A.A., Zameer, H., Ikram, M., Saracoglu, B.O., 2019. Assessing the solar PV power project site selection in Pakistan: Based on AHP-fuzzy VIKOR approach. Environmental Science and Pollution Research 26(29), 30286-30302.

Stillwell, W.G., Seaver, D.A., Edwards, W., 1981. A comparison of weight approximation techniques in multiattribute utility decision making. Organizational behavior and human performance 28(1), 62-77.

Tercan, E., Saracoglu, B.O., Bilgilioğlu, S.S., Eymen, A., Tapkın, S., 2020. Geographic information system-based investment system for photovoltaic power plants location analysis in Turkey. Environmental Monitoring and Assessment 192, 1-26.

The World Bank, G.S.A., (Accessed 01/08/2020).

https://globalsolaratlas.info/download/turkey.

URL-1, Last Access:12/07/2020. https://www.enerjiatlasi.com/sehir/kayseri/.

URL-2, Last Access: 22/07/2020. http://yerbilimleri.mta.gov.tr/anasayfa.aspx.

USGS, Last Access:10/09/2020. https://earthexplorer.usgs.gov/.

Uyan, M., 2017. Optimal site selection for solar power plants using multi-criteria evaluation: a case study from the Ayranci region in Karaman, Turkey. Clean Technologies and Environmental Policy 19(9), 2231-2244.

White, T.P., Lal, N.N., Catchpole, K.R., 2013. Tandem solar cells based on high-efficiency cSi bottom cells: top cell requirements for $>30 \%$ efficiency. IEEE Journal of Photovoltaics 4(1), 208-214.

Zoghi, M., Ehsani, A.H., Sadat, M., javad Amiri, M., Karimi, S., 2017. Optimization solar site selection by fuzzy logic model and weighted linear combination method in arid and semi-arid region: A case study Isfahan-IRAN. Renewable and Sustainable Energy Reviews 68, 986-996. 
Figures

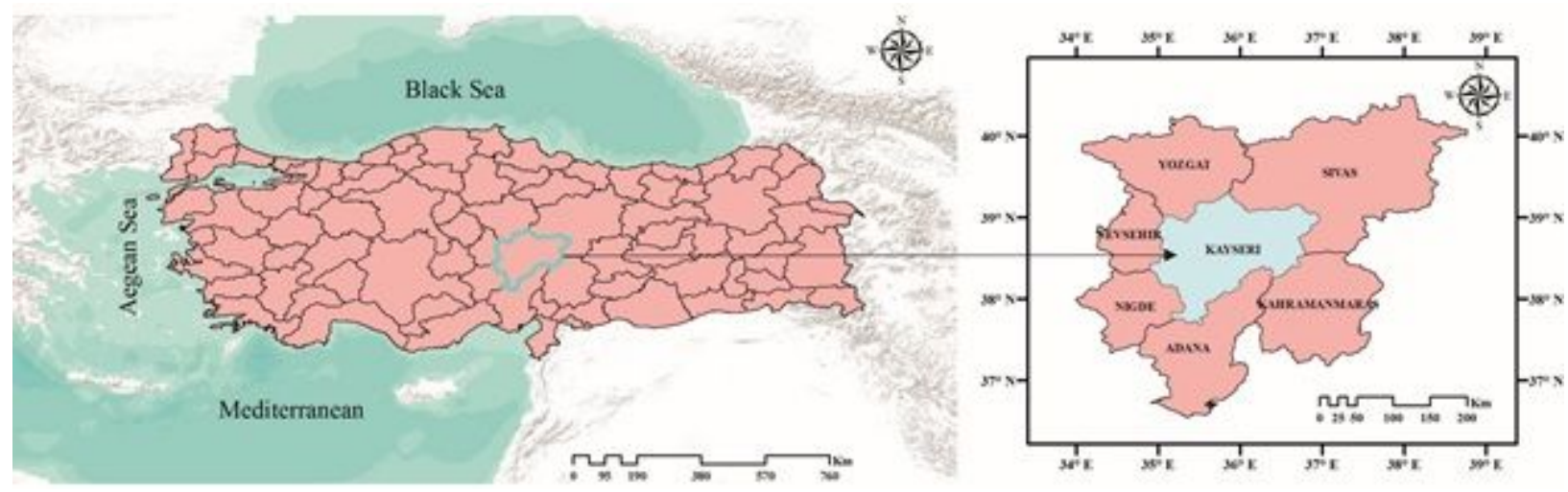

\section{Figure 1}

\section{Location map of study area}

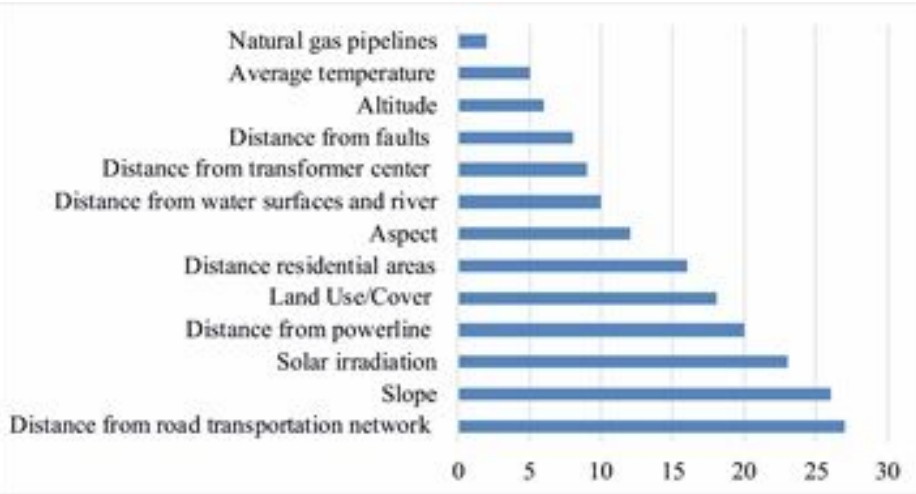

\section{Figure 2}

Most used criteria in the literature for solar PV power plant site selection.

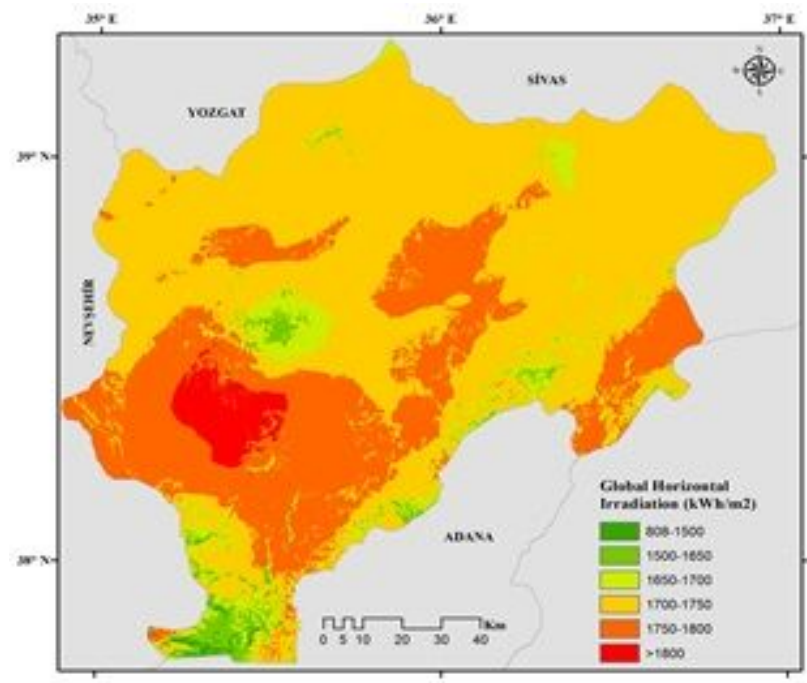

Figure 3 


\section{Reclassified GHI map}

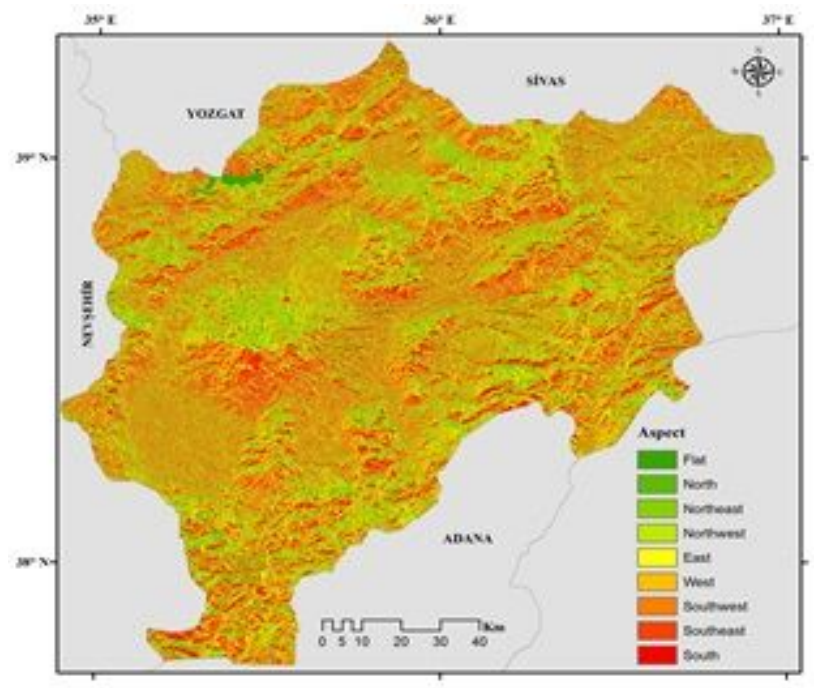

\section{Figure 4}

\section{Reclassified aspect map}

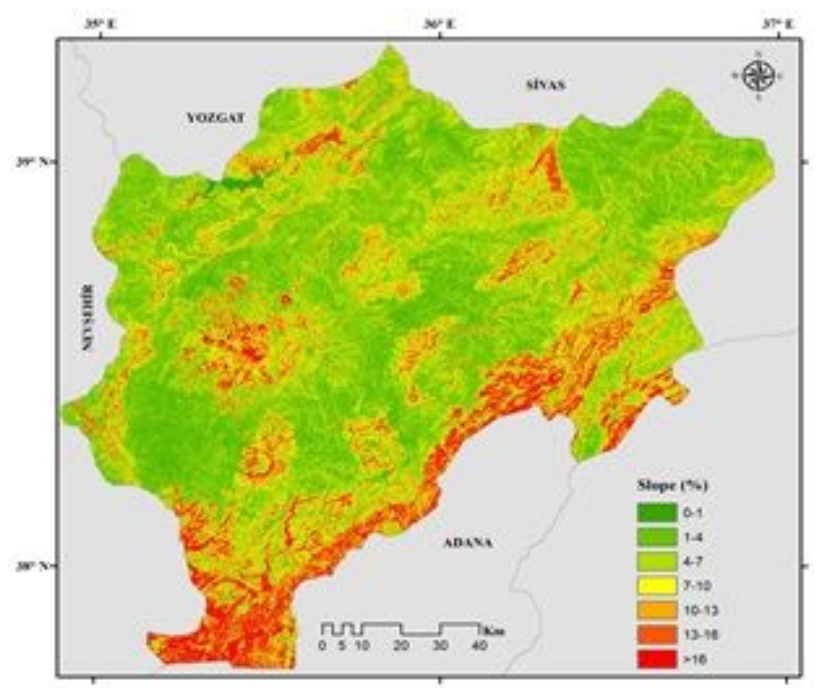

Figure 5

Reclassified slope map 


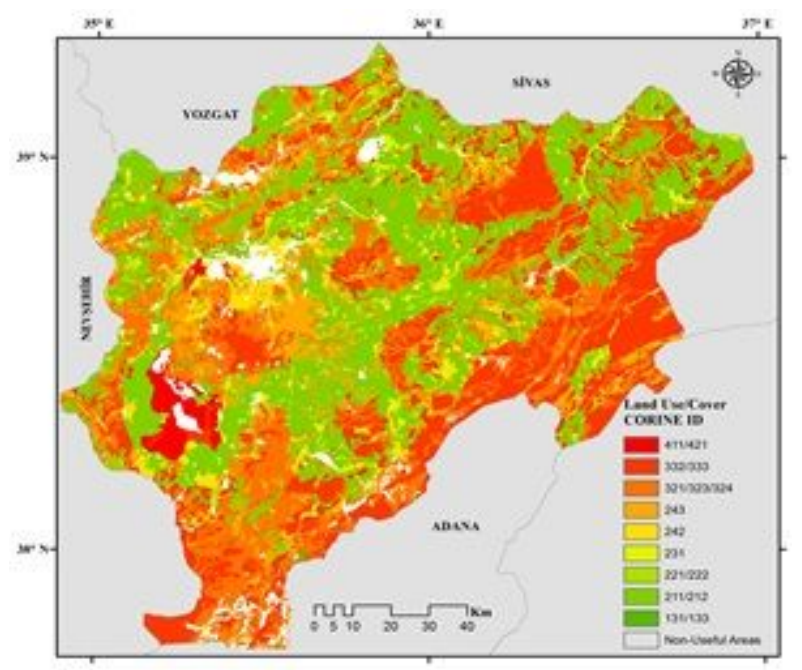

Figure 6

Reclassified land use/cover map

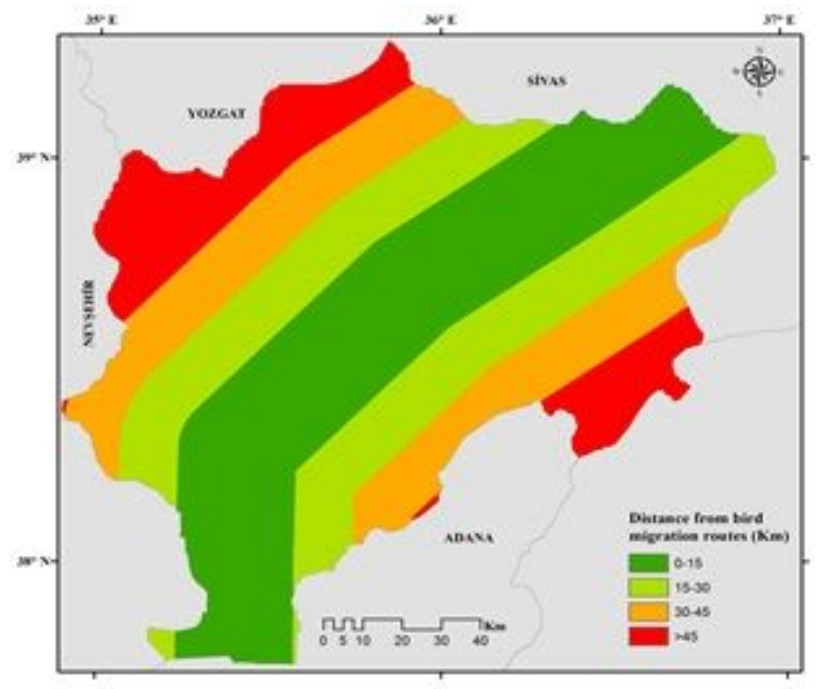

Figure 7

Reclassified distance from bird migration routes map 


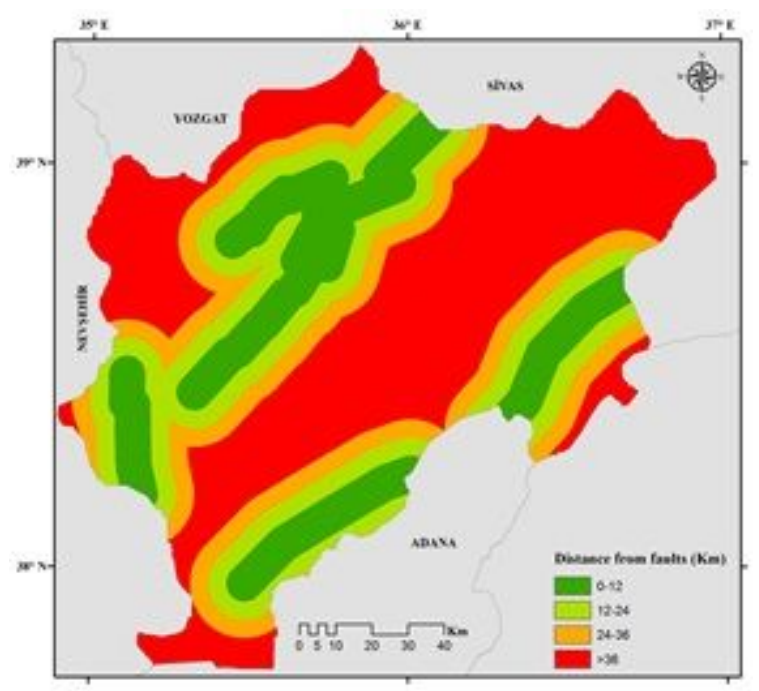

Figure 8

Reclassified distance from faults map

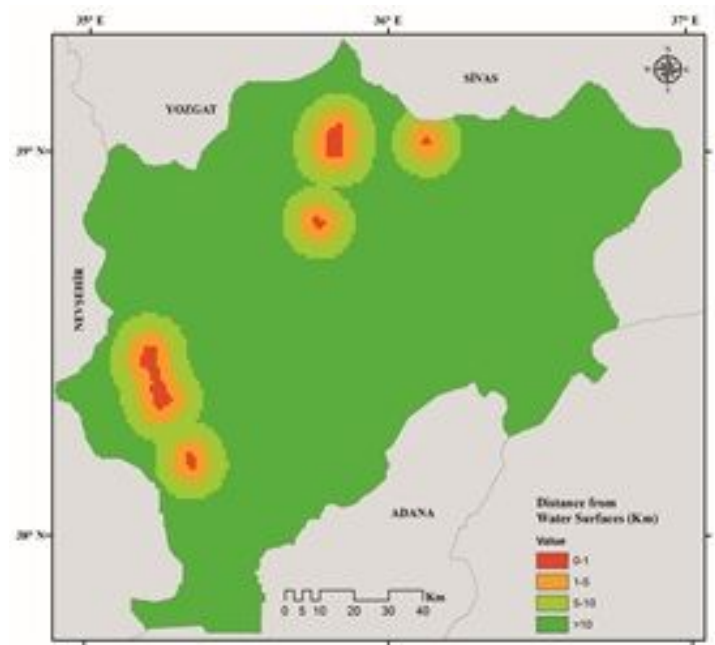

(a)

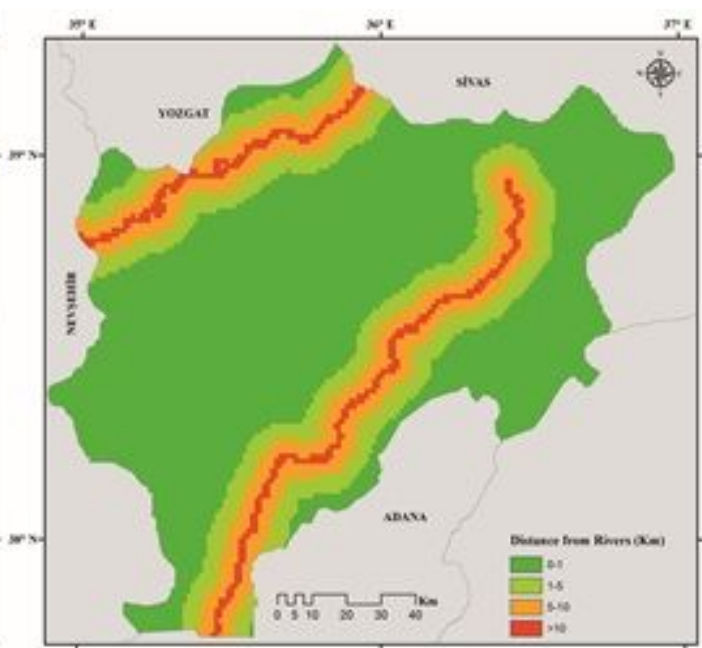

(b)

Figure 9

Reclassified distance from a) water surface and b) rivers maps 


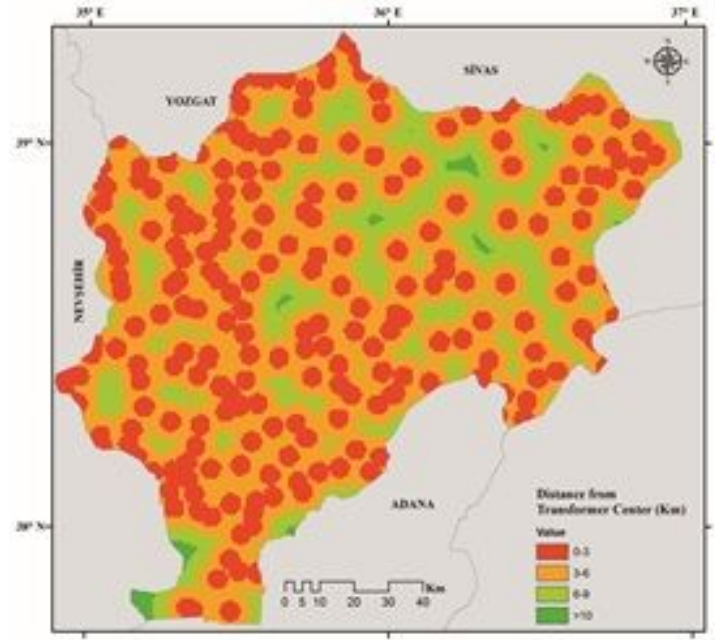

(a)

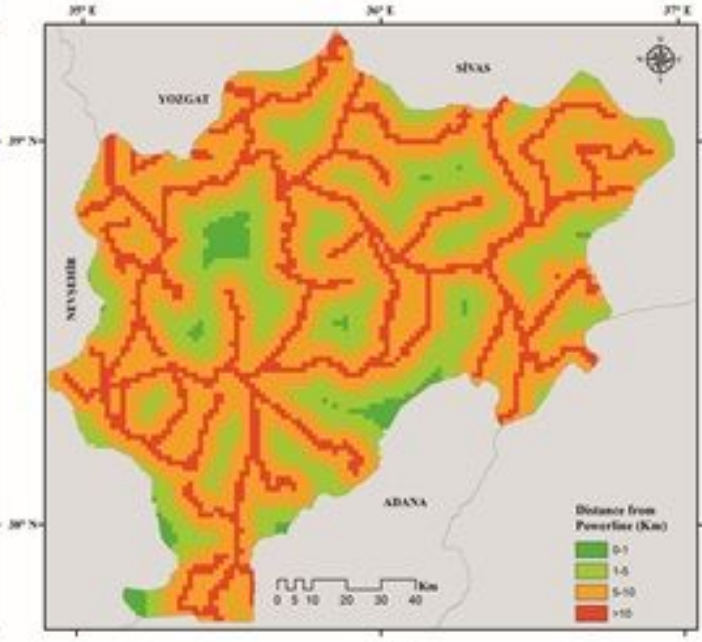

(b)

Figure 10

Reclassified distance from power line and transformer center maps

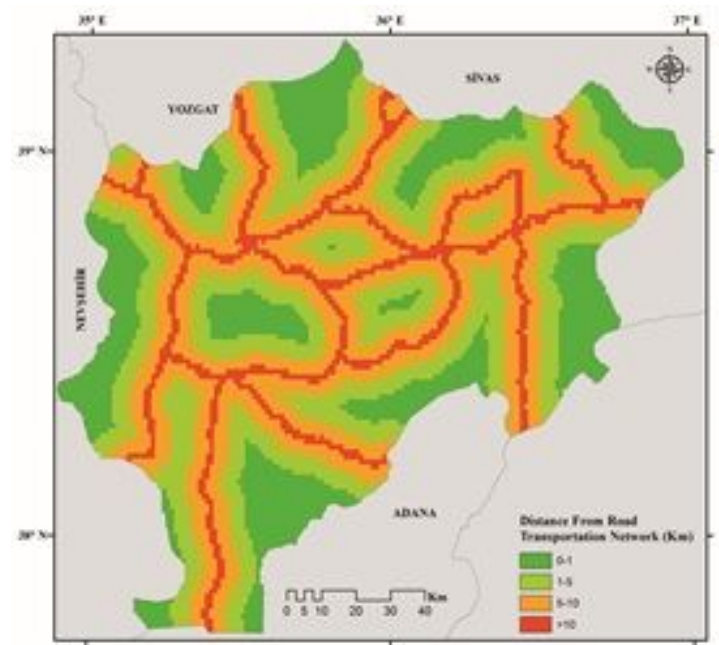

(a)

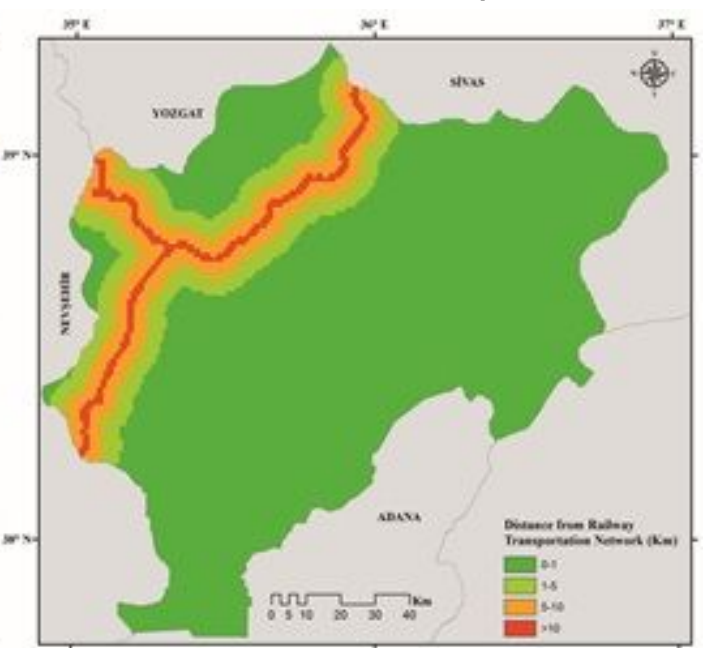

(b)

Figure 11

Reclassified distance from road and railway transportation networks map 


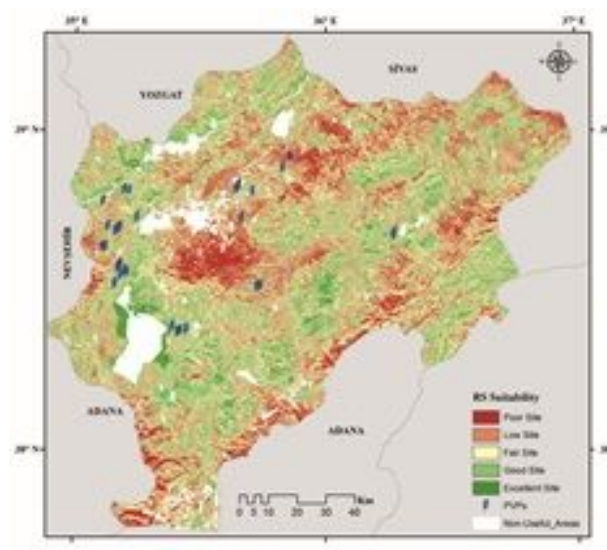

(a)

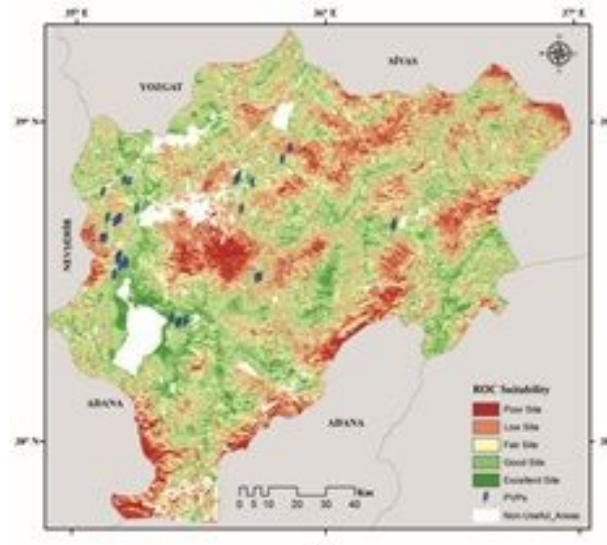

(c)

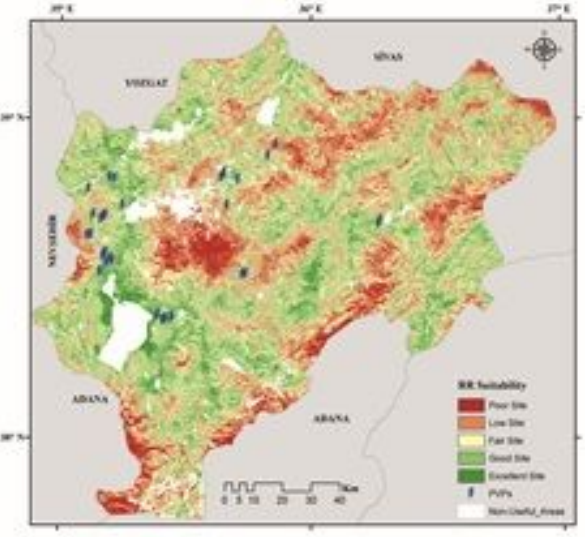

(b)

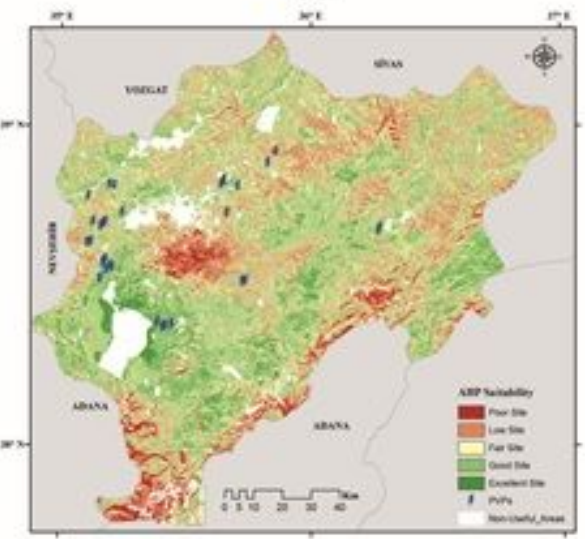

(d)

Figure 12

Suitability map calculated from a) RS, b) RR, c) ROC, and d) AHP 